\begin{tabular}{|c|c|c|}
\hline 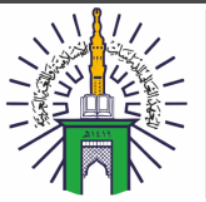 & 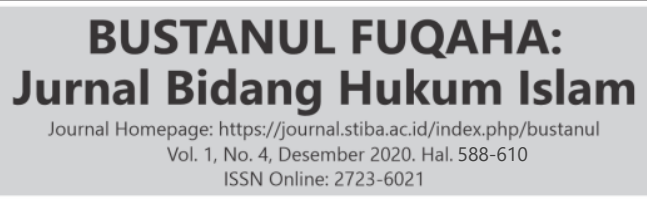 & $\begin{array}{l}\text { Jumal } \\
\text { BUSTANUL } \\
\text { FUQAHA } \\
\text { Jumal Bidang tulum slam }\end{array}$ \\
\hline
\end{tabular}

\title{
HUKUM IDAH PERCERAIAN WANITA YANG HAMIL AKIBAT PERBUATAN ZINA
}

\author{
Rahmat \\ Sekolah Tinggi Ilmu Islam dan Bahasa Arab (STIBA) Makassar \\ Email: rahmatar09@stiba.ac.id \\ Sri Indriani \\ Sekolah Tinggi Ilmu Islam dan Bahasa Arab (STIBA) Makassar \\ Email: sri001858@gmail.com
}

\begin{abstract}
Keywords :
ABSTRACT

Divorce, Pregnant, Period of

Idah, Marriage, Adultery

Marriage and divorce of women who have become pregnant as a result of adultery are problems that are given attention in the discussion of Islamic jurisprudence. Marrying a pregnant woman due to adultery has been a polemic among Islamic scholars since long ago in various countries, including in Indonesia until it was finally stipulated in the Book of Compilation of Islamic Law which became an explanation of the Law on Marriage. Divorce after marriage, which is preceded by pregnancy due to adultery, is also an interesting discussion, especially regarding the issue of idah, or the waiting period for women who are pregnant and subject to divorce. Idah or waiting period has been prescribed by Islam for the noble purpose of maintaining the authenticity of one's lineage so as not to mix with others. This problem was studied from a socio-cultural normative perspective, which compares the arguments and factual conditions, thus giving different values. Law of idah can differ from one woman to another, based on the type of divorce or the process of breaking the marriage bond, as well as on the woman's condition. The law of divorce for women who are pregnant that is the birth of the child they are carrying can also apply to women who are divorced, while they are pregnant as a result of adultery.
\end{abstract}

\section{Kata kunci :}

Cerai, Hamil, Masa Idah,

Nikah, Zina
Pernikahan dan perceraian perempuan yang telah hamil akibat
perbuatan zina menjadi permasalahan yang mendapatkan porsi
pembahasan di dalam hukum fikih Islam. Menikahi perempuan
hamil akibat perbuatan zina menjadi polemik di antara ulama Islam
sejak dahulu di berbagai negara, tidak terkecuali di Indonesia hingga
akhirnya ditetapkan di dalam Kitab Kompilasi Hukum Islam yang
menjadi penjelasan terhadap Undang-undang tentang Perkawinan.
Perceraian pasca pernikahan yang didahului oleh kehamilan akibat
perbuatan zina, juga menjadi pembahasan yang menarik, khususnya
tentang persoalan idah, atau masa tunggu bagi pihak perempuan
yang sedang hamil dan dijatuhi talak. Tujuan penelitian ini adalah
untuk mengetahui hukum pernikahan wanita hamil akibat perbuatan
zina serta masa idahnya setelah perceraian. Tulisan ini 


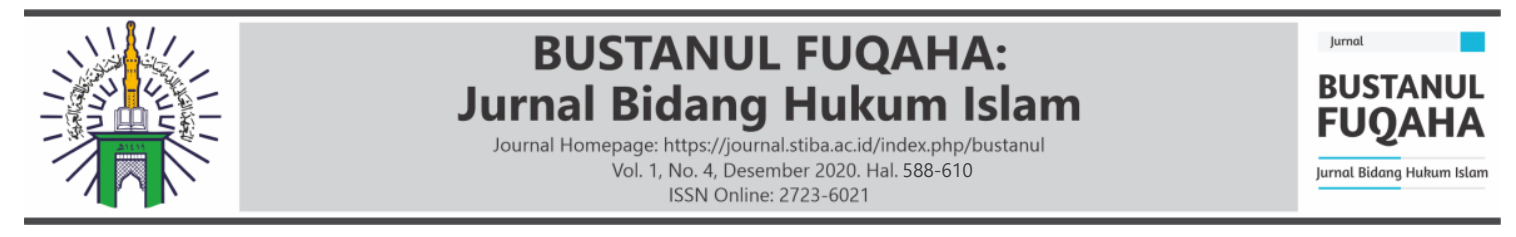

\begin{abstract}
menggunakan metode kualitatif dengan komparatif perspektif normatif sosio kultural, yaitu membandingkan antara dalil dan kondisi faktual. Hasil penelitian menunjukkan bahwa menikahi wanita hamil akibat perbuatan zina, adalah sah, menurut Kitab Kompilasi Hukum Islam, apabila dilakukan oleh laki-laki yang berzina dengannya; dan wanita hamil akibat perbuatan zina, maka idahnya yaitu setelah melahirkan anaknya.
\end{abstract}

\title{
PENDAHULUAN
}

Islam sebagai agama yang menyeluruh dan sempurna telah mengatur segala urusan umat Islam, termasuk urusan pernikahan. Pernikahan merupakan salah satu syariat Islam yang telah diatur oleh Allah dan disebutkan di dalam kalam-Nya yang mulia Qs. al-Rūm/30: 21,

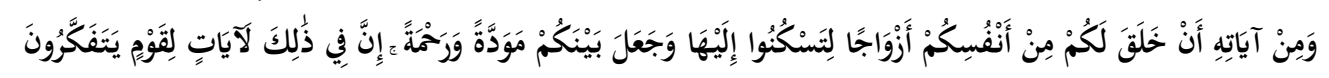

Terjemahnya:

"Dan di antara tanda-tanda (kebesaran)-Nya ialah Dia menciptakan pasanganpasangan untukmu dari jenismu sendiri, agar kamu cenderung dan merasa tenteram kepadanya, dan Dia menjadikan di antaramu rasa kasih dan sayang. Sungguh, pada yang demikian itu benar-benar terdapat tanda-tanda (kebesaran Allah) bagi kaum yang berpikir"1.

Untuk menciptakan rumah tangga yang baik, harus dilalui dengan pernikahan yang $\mathrm{sah}^{2}$. Pernikahan merupakan suatu hal yang sangat sakral dalam kehidupan umat manusia, maka salah satu tujuan pernikahan ialah membentuk keluarga yang bahagia, sakinah, mawadah dan wā rahmah. Dengan pernikahan, seorang laki-laki dan wanita akan sah menjadi pasangan suami istri melalui adanya ijab kabul sebagai janji suci kepada Allah 'Azza wa Jalla. Meskipun demikian, tidak sedikit dari masyarakat yang merusak indah dan sucinya makna pernikahan. Beberapa kasus ditemukan bahwa seorang wanita dinikahi dalam kondisi yang tidak perawan atau menikah dalam kondisi hamil. Salah satu penyebabnya adalah pergaulan bebas di kalangan remaja dan merajalelanya perzinaan di muka bumi.

Fenomena hamil di luar nikah di zaman sekarang ini bukan lagi suatu hal yang baru di tengah masyarakat. Jumlah kasus hamil di luar nikah di Indonesia sendiri semakin memprihatinkan. Setiap tahun, angka tersebut bertambah sejalan dengan semakin longgarnya nilai-nilai sosial, agama dan pergaulan di tengah masyarakat. Padahal zina merupakan dosa besar yang Allah murkai dan termasuk perbuatan keji setelah syirik dan pembunuhan. Allah swt. berfirman dalam Q.S. al-Isrā'/17:32,

${ }^{1}$ Kementrian Agama Republik Indonesia, Mushaf Tajwid dan Terjemah (t. Cet; Solo: Penerbit Fatwa, 2017), h.406.

${ }^{2}$ Armaidi Tanjung, Free Sex No Nikah Yes (Cet.I; Jakarta: Amzah, 2007), h.109-110. 


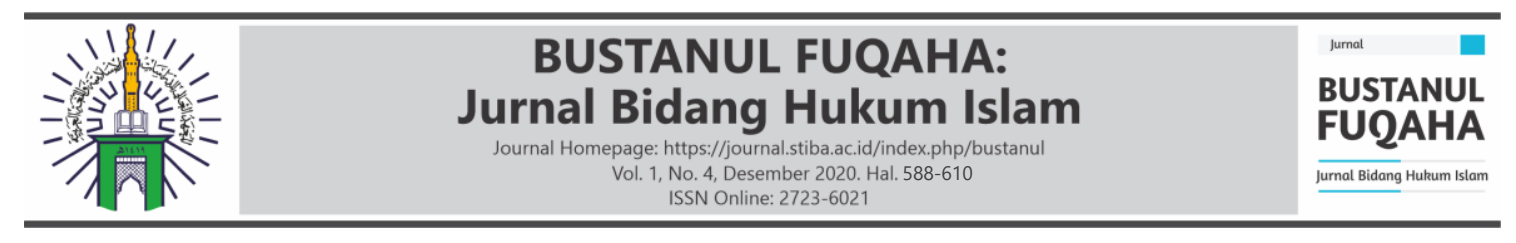

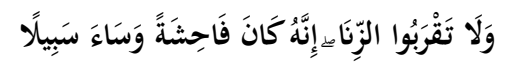

Terjemahnya:

"Dan janganlah kamu mendekati zina; Sesungguhnya zina itu adalah suatu perbuatan yang keji dan suatu jalan yang buruk"3.

Dalam ayat lainnya, Allah swt. berfirman,

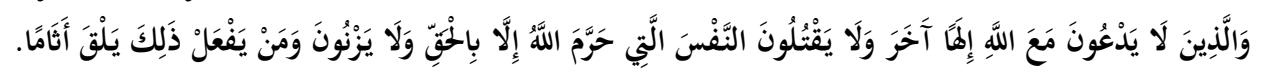

Terjemahnya:

"Dan orang-orang yang tidak menyembah tuhan yang lain beserta Allah dan tidak membunuh jiwa yang diharamkan Allah (membunuhnya) kecuali dengan (alasan) yang benar, dan tidak berzina, barang siapa yang melakukan yang demikian itu, niscaya dia mendapat (pembalasan) atas dosa(nya) (Q.S. al-Furqān/25: 68)"4.

Dalam hadis Nabi saw., beliau bersabda,

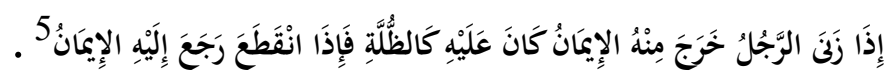

Artinya:

"Jika seseorang itu berzina, maka iman itu keluar dari dirinya seakan-akan dirinya sedang diliputi oleh gumpalan awan (di atas kepalanya). Jika dia lepas dari zina, maka iman itu akan kembali padanya."

Inilah besarnya bahaya zina. Oleh karenanya, syariat Islam yang mulia dan begitu sempurna sampai menutup berbagai pintu agar setiap orang tidak terjerumus ke dalamnya. Namun, itulah yang terjadi jika hal ini dilanggar, akhirnya terjadilah apa yang terjadi. Terjerumuslah dalam dosa besar zina karena tidak mengindahkan berbagai jalan yang dapat mengantarkan pada zina seperti bentuk pacaran yang dilakukan muda-mudi saat ini. Jadilah di antara mereka hamil di luar nikah ${ }^{6}$.

Seorang wanita yang hamil di luar nikah akan berusaha mencari cara untuk menutup aibnya, begitu pula dengan pihak keluarga, pasti akan berusaha menutup aib anggota keluarganya, dan cara yang banyak dilakukan untuk menutup aib tersebut ialah dengan jalan pernikahan. Namun, sangat disayangkan jika wanita yang hamil di luar nikah, dinikahkan dengan laki-laki lain, bukan dengan laki-laki yang menghamilinya. Hal tersebut tentu akan berpengaruh pada nasab anaknya, dan kemungkinan masalah lain

${ }^{3}$ Kementrian Agama Republik Indonesia, Mushaf Tajwid dan Terjemah (t. Cet; Solo: Penerbit Fatwa, 2017), h.285.

${ }^{4}$ Kementrian Agama Republik Indonesia, Mushaf Tajwid dan Terjemah (t. Cet; Solo: Penerbit Fatwa, 2017), h.366.

${ }^{5}$ HR. Abu Daud no. 4690 dan Tirmidzi no. 2625. Syaikh Al Albani mengatakan bahwa hadis ini shahih.

${ }^{6}$ Muhammad Abduh Tuasikal, "Menikahi Wanita Hamil Karena Zina", Artikel, https://rumaysho.com/928-menikahi-wanita-hamil-karena-zina.html (diakses pada tanggal 25 April 2020). 


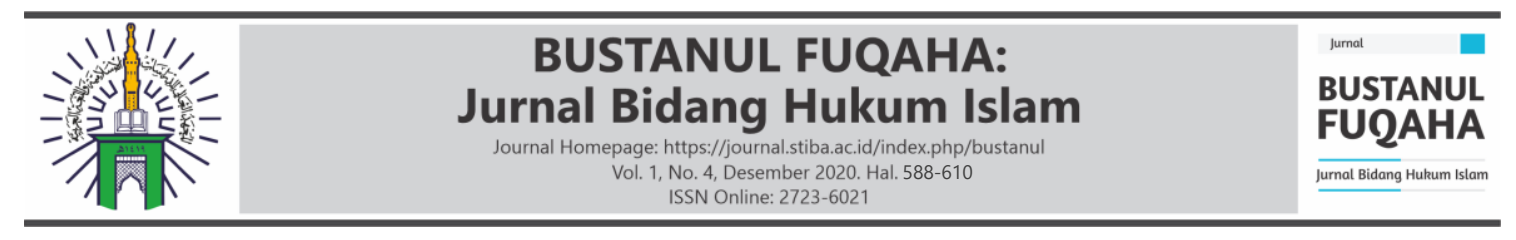

yang akan terjadi ialah ketika laki-laki yang telah menjadi suaminya tersebut mengetahui bahwa wanita yang dinikahinya ternyata tengah berbadan dua. Tentunya, perasaan kecewa yang akan dialami oleh suami. Suami mana yang tidak akan cemburu melihat kondisi istrinya yang telah disentuh oleh laki-laki lain dengan jalan yang tidak diridai Allah. Dengan demikian, disebabkan karena masalah tersebut, akhirnya suami memutuskan untuk menceraikan istrinya.

Perceraian ialah menghilangkan ikatan perkawinan sehingga setelah hilangnya ikatan perkawinan itu istri tidak halal lagi bagi suaminya ${ }^{7}$. Berbicara mengenai masalah perceraian, tentu suami istri tidak serta merta langsung berpisah. Di dalam Islam, ada istilah yang dikenal dengan masa idah (masa tunggu). Masa idah merupakan masa yang ditetapkan untuk suami ingin kembali kepada istrinya atau ingin menceraikannya. Adapun persoalan idah, sejatinya telah terjadi sebelum datangnya Islam (masa jahiliah) ${ }^{8}$, dan setelah diutusnya Nabi saw., maka persoalan idah semakin jelas dalam Al-Qur'an dan hadis Nabi saw. Hal ini menunjukkan makna bahwa Islam adalah agama yang mengajarkan konsep keadilan (al-hikmah), di mana masing-masing orang diberikan haknya, yang sesuai fitrahnya, menempatkan sesuatu pada tempatnya, tidak melampaui batas, dan agar seseorang terjaga keimanannya, serta terhindar dari dosa9 .

Idah adalah suatu kewajiban yang harus dijalankan oleh setiap wanita pasca cerai dari suaminya atau bagi mereka yang ditinggal mati suaminya ${ }^{10}$. Masa idah merupakan syariat Allah 'Azza wa Jalla yang diatur dalam Qs. al-Baqarah/2: 228,

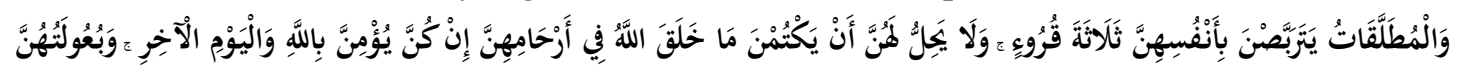

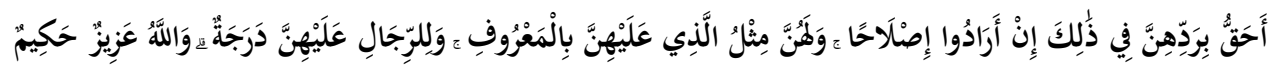

Terjemahnya:

"Dan para istri yang diceraikan (wajib) menahan diri mereka (menunggu) tiga kali qurū'. Tidak boleh bagi mereka menyembunyikan apa yang diciptakan Allah dalam rahim mereka, jika mereka beriman kepada Allah dan hari akhir. Dan para suami mereka lebih berhak kembali kepada mereka dalam (masa) itu, jika mereka menghendaki perbaikan. Dan mereka (para wanita) mempunyai hak seimbang dengan kewajibannya menurut cara yang patut. Tetapi para suami, mempunyai kelebihan di atas mereka. Allah Mahaperkasa, Mahabijaksana"'11.

\footnotetext{
${ }^{7}$ Abd. Rahman Ghazaly, Fiqh Munākahāt (Cet. II; Jakarta: Prenada Media Grup, 2006), h.192.

${ }^{8}$ Usman, M. H., \& Yunta, A. H. D., "Koreksi Hukum Islam Terhadap Hukum Jahiliah", BUSTANUL FUQAHA: Jurnal Bidang Hukum Islam 1, no. 1 (2020): h. 11-12.

${ }^{9}$ Rahman, R. A., “Konsep Keadilan dalam Alquran”, NUKHBATUL'ULUM: Jurnal Bidang Kajian Islam 2, no. 1 (2016): h. 174. 2019), h. 8 .

${ }^{10}$ Vivi Kurniawati, Kupas Habis Hukum Idah Wanita (3) (Cet.I; Jakarta: Rumah Fikih Publishing,

${ }^{11}$ Departemen Agama R.I., Alquran dan Terjemahnya(t. Cet; Jakarta Timur: Ummul Qura, 2017), h.36.
} 


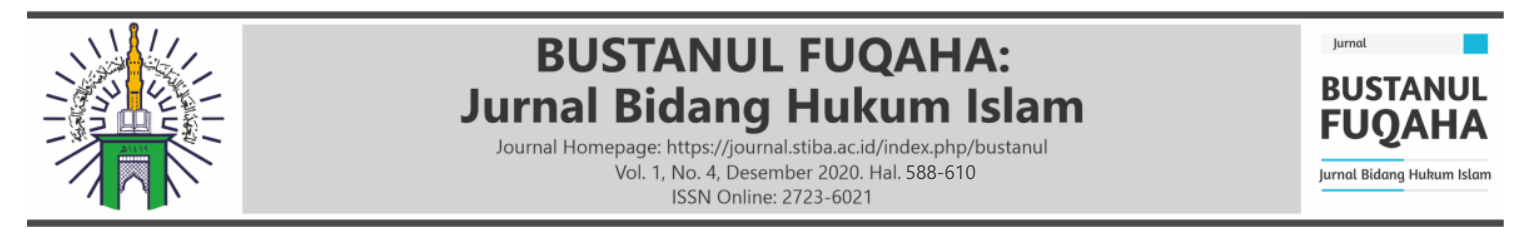

Dari ayat tersebut dapat diketahui bahwa secara umum idah bagi seorang wanita yang diceraikan itu tiga kali quñ ' (batas masa haid atau suci setelah perpisahan). Namun, dalam buku-buku fikih dijumpai idah memiliki berbagai macam jenis. Misalnya, idah bagi wanita hamil itu berbeda dengan idah wanita yang tidak hamil dan idah bagi wanita yang sudah digauli (jimak) itu berbeda dengan idah wanita yang belum digauli.

Berangkat dari masalah-masalah yang disebutkan sebelumnya, maka tulisan ini dibuat sebagai inisiatif untuk mengangkat sebuah pokok permasalahan. Permasalahan tersebut berhubungan dengan wanita yang diceraikan dalam kondisi hamil, dengan metodologi kualitatif komparatif, antara dalil-dalil syariah dan kondisi sosio kultural masyarakat, juga perbandingan antara pandangan-pandangan ulama Islam. Pembahasan terhadap permasalahan ini, dirumuskan melalui pertanyaan ihwal bagaimana idah bagi wanita hamil di luar nikah tersebut?; Bagaimana masa idahnya ditentukan, sebagai idah wanita yang diceraikan dalam kondisi hamil atau dihitung sebagai idah wanita yang diceraikan sebelum berjimak?.

Kajian ini bertujuan untuk mengetahui lebih banyak tentang hukum pernikahan atas wanita yang sedang hamil, akibat perzinahan, dan juga penentuan masa idah baginya, apabila terjadi perceraian setelah pernikahan ini. Penelitian ini dilakukan dan berguna bagi kaum akademis, sebagai referensi untuk penelitian-penelitian lanjutan, dan juga bagi masyarakat luas, sebagai pegangan hukum di dalam tindakan mereka untuk kondisi yang terjadi.

\section{PEMBAHASAN}

\section{Konsep Idah}

Secara bahasa, al-'Iddah (العِدَّة) ialah maṣdar dari (عَدَّ يَعُدُّ عَدَا) diambil dari kata bilangan dan hitungan, karena ia mencakup hitungan masa haid dan bulan. Secara syariat, idah ialah nama untuk masa tertentu di mana seorang wanita menantinya sebagai ibadah kepada Allah, atau untuk berduka atas meninggalnya suami, atau untuk memastikan bersihnya rahim ${ }^{12}$. Adapun dalam buku Taysìr al-'Allām Syarh 'Umdah alAhkām, disebutkan bahwa idah ialah masa menunggu yang terbatas bagi perempuan untuk tidak kawin lagi (dengan laki-laki lain) setelah bercerai dengan suaminya ${ }^{13}$.

Pada Kompilasi Hukum Islam Pasal 152 ayat (1) Undang-undang Nomor 1 Tahun 1974 Tentang Perkawinan telah dijelaskan bahwa: "Bagi seorang istri yang putus perkawinannya berlaku waktu tunggu atau idah, kecuali qabla al dukhūl dan perkawinannya putus bukan karena kematian suami"14. Dilanjutkan pada pasal yang

\footnotetext{
${ }^{12}$ Abdullaḥ bin Muhammad at-Ţayyār, dkk., al-Fiqh al-Muyassar (Cet. II; Riyāḍ: Madāru alWaṭi Lii an-Nasyr, 2016), h.161.

${ }^{13}$ Abdullah bin Ahmad bin Muhammad bin Qudāmah bin Miqdam Bin Nașr bin Abdullah, Taysīr al- 'Allām Syarḥ 'Umdah al-Ahkām (Cet. I; Kairo: Dār al-Mugnī, 1427 H/2007 M), h.67.

${ }^{14}$ Tim Redaksi Nuansa Aulia, Kompilasi Hukum Islam (Cet. VII; Bandung: CV. Nuansa Aulia, 2017), h.43.
} 


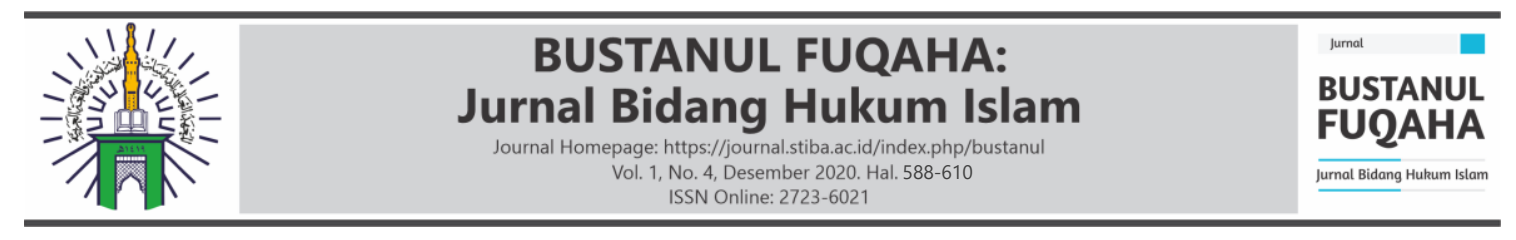

sama ayat (3): "Tidak ada waktu tunggu bagi yang putus perkawinan karena perceraian sedang antara janda tersebut dengan bekas suaminya qabla al dukhū ' $^{\prime}$.

\section{Dalil Normatif tentang Idah}

Dasar hukum masalah idah ialah kitabullah, sunah Nabi Șallallāhu 'alaihi wa Sallam, dan ijmak ulama ${ }^{16}$.

\section{Al-Qur'an}

Dalil yang mensyariatkan idah berdasarkan firman Allah Ta'āla dalam Q.S. alBaqarah/2:228,

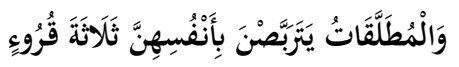

Terjemahnya:

"Dan para istri yang diceraikan (wajib) menahan diri mereka (menunggu) tiga kali quñ '..."17

Dan juga firman Allah Ta'āla Q.S. al-Ṭalāq/65:4,

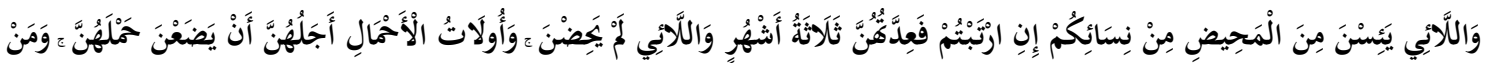

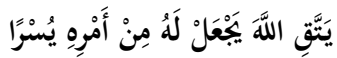

Terjemahnya:

"Wanita-Wanita yang tidak haid lagi (menopause) di antara istri-istrimu jika kamu ragu-ragu (tentang masa idahnya) maka masa idahnya ialah tiga bulan; dan begitu (pula) wanita-wanita yang tidak haid. Sedangkan wanita-wanita yang hamil, waktu idah mereka itu sampai mereka melahirkan kandungannya..."18.

Dan juga firman Allah Ta'āla Q.S. al-Aḥzāb/33:49,

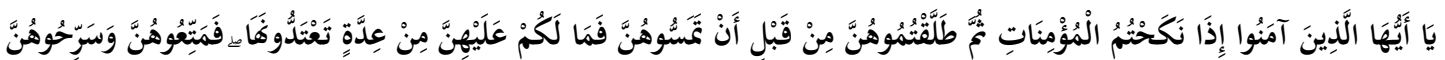

$$
\begin{aligned}
& \text { سَرَاحَا بمِيلاً } 19
\end{aligned}
$$

Terjemahnya:

"Hai orang-orang yang beriman, apabila kamu menikahi perempuan- perempuan yang beriman, kemudian kamu ceraikan mereka sebelum kamu mencampurinya Maka sekali-sekali tidak wajib atas mereka 'idah bagimu yang kamu minta 2017), h.44

${ }^{15}$ Tim Redaksi Nuansa Aulia, Kompilasi Hukum Islam (Cet. VII; Bandung: CV. Nuansa Aulia,

${ }^{16}$ Abdullah bin Ahmad bin Muhammad bin Qudāmah bin Miqdam Bin Nașr bin Abdullah, Taysīr al- 'Allām Syarḥ 'Umdah al-Ahkām (Cet. I; Kairo: Dār al-Mugniy, 1427 H/2007 M), h.

${ }^{17}$ Kementrian Agama Republik Indonesia, Mushaf Tajwid dan Terjemah (t. Cet; Solo: Penerbit Fatwa, 2017), h.36.

${ }^{18}$ Kementrian Agama Republik Indonesia, Mushaf Tajwid dan Terjemah, h.558.

${ }^{19}$ Kementrian Agama Republik Indonesia, Mushaf Tajwid dan Terjemah (t. Cet; Solo: Penerbit Fatwa, 2017), h.424. 


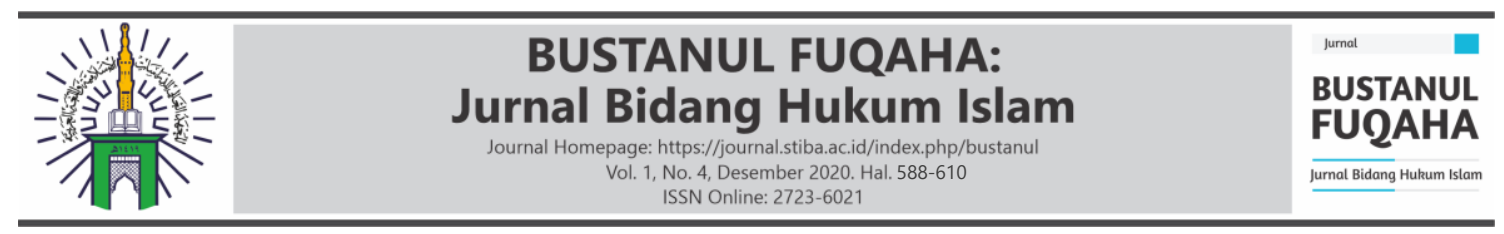

menyempurnakannya. Maka berilah mereka mut'ah dan lepaskanlah mereka itu dengan cara yang sebaik- baiknya”.

\section{Sunah}

Dalam hadis al-Miswar bin Makhramah ra. dia berkata:

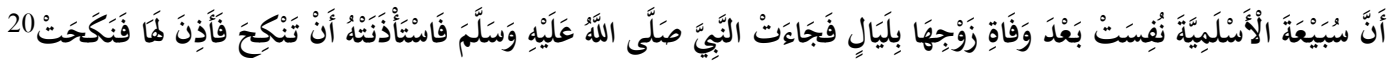
Artinya:

"Subai'ah al-Aslamiyyah melahirkan beberapa hari setelah suaminya wafat, lalu beliau menemui Nabi shallallāhu'alaihi wa sallam dan meminta izin untuk menikah. Maka beliau pun mengizinkannya."

Dalam hadis Abu Sa'id mengenai para wanita tawanan dari suku Authas berupa sabda Nabi Sallallāhu 'alaihi wa Sallam²1.

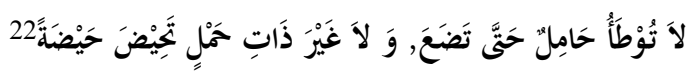

Artinya:

"Wanita hamil tidak boleh digauli hingga melahirkan, dan wanita yang tidak hamil hingga satu kali haid'

\section{Ijmak}

Para ulama sudah menyepakati masalah idah ini, yang didasarkan pada nas-nas Al-Qur' an dan sunah Nabi Șallallāhu 'alaihi wa Sallam yang banyak ${ }^{23}$.

\section{Macam-Macam Idah}

Masa idah itu terdapat tiga macam, yaitu idah dengan hitungan qurū', idah dengan hitungan bulan (kamariah) dan idah sampai dengan melahirkan. Adapun wanitawanita yang mendapatkan idah ada enam macam, yaitu wanita yang sedang hamil, wanita yang ditinggal mati suaminya, wanita yang ditalak suaminya, wanita yang tidak haid karena masih kecil atau karena menopause, wanita yang kehilangan masa haidnya dan wanita yang kehilangan suaminya atau tidak diketahui keberadaan dan kondisinya ${ }^{24}$.

Adapun dalam buku al-Fiqhu al-Muyassar, idah wanita dikategorikan terbagi menjadi dua macam: idah wafat dan idah perceraian (talak). Pertama, idah wafat, yaitu;

${ }^{20}$ (HR. al-Bukhari no. 4908).

${ }^{21}$ Abū Mālik Kamāl bin al-Sayyid Sālim, Șahih Fiqh al-Sunnah, Jilid 3 (t. Cet; Mesir: alMaktabah al-Tawfĩqiyyah, 2003), h..

${ }^{22} \mathrm{Abū}$ 'Umar Yūsuf bin 'Abdillāh bin 'Abdu al-Barr al-Namrīy al-Qurtbīy, al-Tamhīd limā fí alMuwațta’ min al-Ma'āniy wa al-Asānīd fi Hadiśsi Rasūlilāh (t. Cet; Lebanon: al-Maktabah alAșrīyyah,1428 H), h.142.

${ }^{23}$ Abdullah bin Ahmad bin Muhammad bin Qudāmah bin Miqdam Bin Nașr bin Abdullah, Taysīr al- 'Allām Syarḥ 'Umdah al-Ahkām (Cet. I; Kairo: Dār al-Mugniy, 1427 H/2007 M), h.

${ }^{24}$ Tim Ulin Nuha Ma’had Aly al-Nur, Fiqih Munākahāt (Cet. I, Solo: Kiswah Media 2018), h.196. 


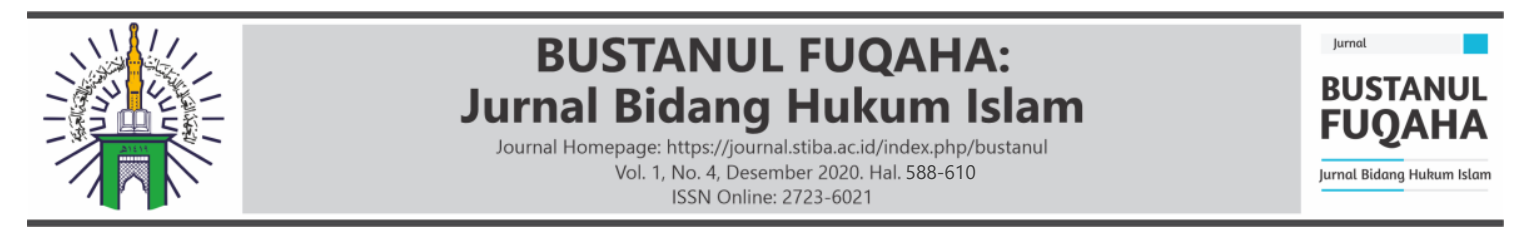

idah wajib atas istri yang ditinggal wafat oleh suaminya, keadaannya tidak lepas dari dua kemungkinan, hamil atau tidak hamil. Kedua, idah wafat, yaitu; idah yang wajib atas wanita yang berpisah dengan suaminya disebabkan oleh fasakh (dibatalkan stat us perkawinannya), talak, atau khuluk sesudah terjadinya persetubuhan. Keadaan wanita ini tidak lepas dari beberapa kemungkinan ${ }^{25}$ : (1) Wanita yang berstatus hamil; (2) Wanita yang tidak berstatus hamil; (3) Wanita yang tidak haid, karena umurnya masih kecil atau sudah menopause karena lanjut usia.

\section{Hikmah Disyariatkannya Idah}

Sungguh Allah Tabāraka wa Ta'āla telah menetapkan idah ini yang mana pada masa idah tersebut, istri yang dicerai agar menahan diri untuk tidak kawin lagi dengan laki-laki lain, karena banyak hikmah dan rahasia besar yang terkandung di dalamnya, di antaranya ${ }^{26}$ : (1) Dapat diketahui bersihnya rahim supaya sperma dua orang laki-laki tidak terhimpun dalam satu rahim, sehingga urutan nasab menjadi tidak jelas dan bercampurnya dua sperma dalam satu rahim tersebut akan melahirkan kerusakan dan keburukan; (2) Mengagungkan urgensi akad nikah, meninggikan derajatnya, dan menampakkan kemuliaanya; (3) Memperpanjang kesempatan untuk rujuk bagi laki-laki yang telah mentalaknya, karena barangkali di lain hari dia menyesalinya, sehinggga dia memiliki rentang waktu yang memungkinkan untuk rujuk kembali kepada istrinya. Hikmah-hikmah ini tampak jelas dalam idah bagi talak raj'i dan ini disyariatkan oleh ayat alquran surah al-Ṭalāq/65:1,

$$
\text { لالَ تَدْرِي لَعَلَّ اللَّهَ يُحْدِثُ بَعْدَ ذَلِكَ أَمْرًا }
$$

Terjemahnya:

“Kamu tidak mengetahui barangkali Allah mengadakan sesudah itu suatu hal yang baru' ${ }^{27}$.

Dalam idah juga pemenuhan hak suami dan upaya menampakkan rasa kehilangan, ini juga berkaitan dengan hak istri yang ditinggal mati suaminya. Idah juga memiliki hikmah yang banyak yang bertalian dengan hak suami, hak istri, hak anak dan hak Allah (sebelum semua itu) dengan cara menjalankan perintah-Nya. Ada rahasia besar (dari sekian banyak rahasia syariat Allah) dibalik ketaatan menjalankan segenap perintah-Nya. ${ }^{28}$

${ }^{25}$ Abdullah bin Muhammad at-Ţayyār, dkk., al-Fiqh al-Muyassar (Cet. II; Riyāḍ: Madāru alWațini Lii an-Nasyr, 2016), h.161.

${ }^{26}$ Abdullah bin Ahmad bin Muhammad bin Qudāmah bin Miqdam Bin Nașr bin Abdullah, Taysīr al- 'Allām Syarḥ 'Umdah al-Ahkām (Cet. I; Kairo: Dār al-Mugniy, 1427 H/2007 M). h

${ }^{27}$ Kementrian Agama Republik Indonesia, Mushaf Tajwid dan Terjemah (t. Cet; Solo: Penerbit Fatwa, 2017), h.558.

${ }^{28}$ Abdullah bin Ahmad bin Muhammad bin Qudāmah bin Miqdam Bin Nașr bin Abdullah, Taysīr al- 'Allām Syarḥ 'Umdah al-Ahkām (Cet. I; Kairo: Dār al-Mugniy, 1427 H/2007 M). h 


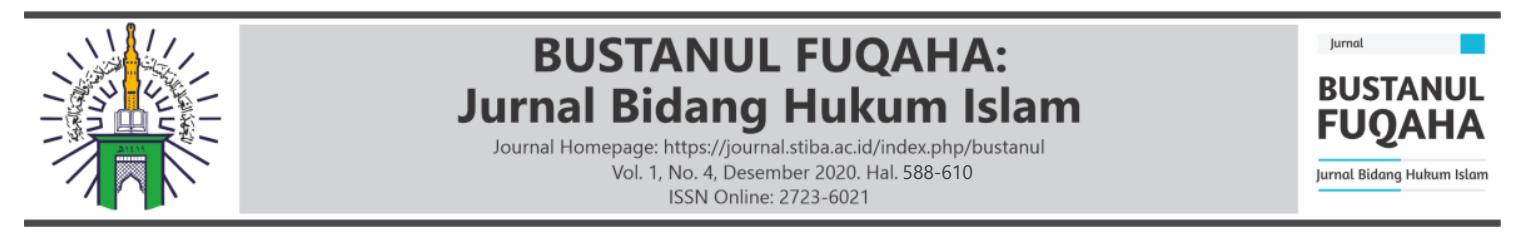

\section{Konsep Perceraian}

Menurut Muḥammad 'Alī al-Ṣābūnī, perceraian (talak) diartikan menguraikan atau melepaskan ikatan pernikahan. Kata perceraian berasal dari kata (الإنطِلاكَ) yang berarti

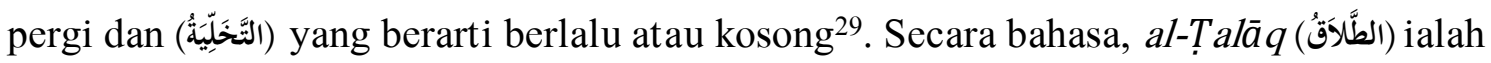
melepaskan. Dikatakan (طَلَقَتِ النَََّقُقة) artinya unta itu lepas, yaitu bila unta itu lepas ke mana pun yang dikehendakinya ${ }^{30}$. Sedangkan secara syariat ialah ia melepaskan ikatan perkawinan. Definisi menurut syariat ini ialah salah satu maknanya secara bahasa yang bersifat umum. Imam al-Haramain (Imam al-Juwaini) berkata, "Talak ialah lafaz yang biasa berlaku pada era jahiliyah yang kemudian syariat membenarkannya"31.

\section{Dalil Normatif tentang Perceraian}

Hukum talak ditetapkan berdasarkan kitabullah, sunah Rasul-Nya, ijmak ulama, dan kias $\operatorname{sahih}^{32}$.

\section{Al-Qur'an}

Hukum disyariatkannya talak berdasarkan firman Allah Ta'āla Qs. al-Ṭalāq/65:1,

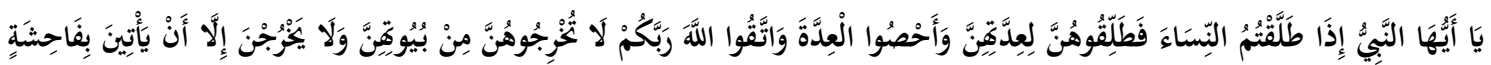

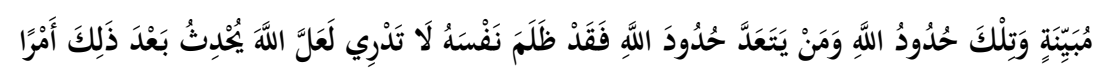

Terjemahnya:

"Wahai Nabi! Apabila kamu menceraikan istri-istrimu maka hendaklah kamu ceraikan mereka pada waktu mereka dapat (menghadapi) idahnya (yang wajar), dan hitunglah waktu idah itu, serta bertakwalah kepada Allah Tuhanmu. Janganlah kamu keluarkan mereka dari rumahnya dan janganlah (diizinkan) keluar kecuali jika mereka mengerjakan perbuatan keji yang jelas. Itulah hukumhukum Allah, dan barangsiapa melanggar hukum-hukum Allah, maka sungguh, dia telah berbuat zalim terhadap dirinya sendiri. Kamu tidak mengetahui barangkali setelah itu Allah mengadakan sesuatu ketentuan yang baru" ${ }^{33}$.

Dan juga firman Allah Ta'āla Q.S. al-Baqarah/2: 229,

\footnotetext{
${ }^{29}$ Muhạmmad 'Alī al-Ṣābūnī, Rawāi'u al-Bayān Tafs̄ì āyāti al-Ahkām Min alquran, Jilid 1 (t. Cet; Libanon: al-Maktabah al-'Așriyyah, 1438 H/2017 M), h. 298.

${ }^{30}$ Abdullaḥ bin Muḥammad al-Ṭayyār, dkk., al-Fiqh al-Muyassar (Cet. II; Riyāḍ: Madāru alWați Lii an-Nasyr, 2012), h.

${ }^{31}$ Abdullah bin Ahmad bin Muhammad bin Qudāmah bin Miqdam Bin Nașr bin Abdullah, Taysīr al- 'Allām Syarḥ 'Umdah al-Ahkām (Cet. I; Kairo: Dār al-Mugniy, 1427 H/2007 M). h.

${ }^{32}$ Abdullah bin Ahmad bin Muhammad bin Qudāmah bin Miqdam Bin Nașr bin Abdullah, Taysīr al-'Allām Syarh 'Umdah al-Ahkām, h .

${ }^{33}$ Kementrian Agama Republik Indonesia, Mushaf Tajwid dan Terjemah (t. Cet; Solo: Penerbit Fatwa, 2017), h.558.
} 


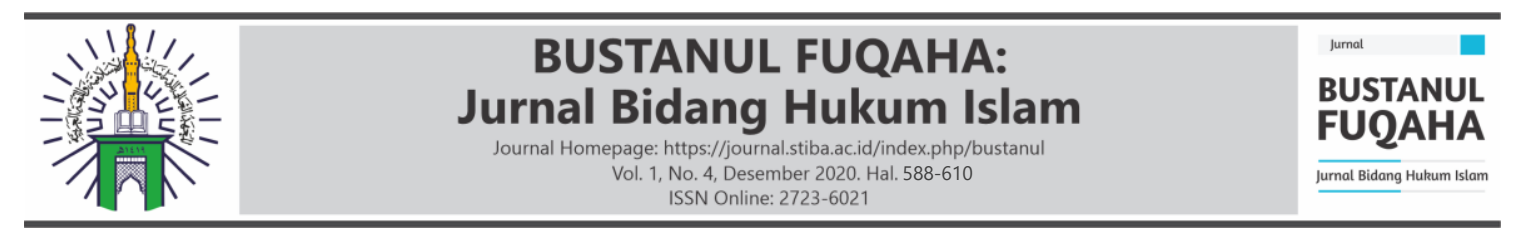

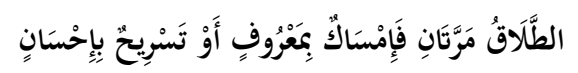

Terjemahnya:

" Talak (yang dapat dirujuk) itu dua kali. Setelah itu boleh rujuk lagi dengan cara yang makruf atau menceraikan dengan cara yang baik"34.

\section{Sunah}

Adapun dalil dari as-Sunnah sebagaimana hadis Ibnu 'Umar radiallahu 'anhu yang menceraikan istrinya di saat haid, maka Nabi Saw bersabda kepada 'Umar radiallāhu 'anhus',

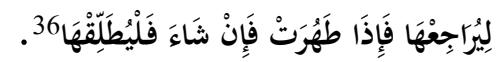

Artinya:

"Hendaklah dia merujuknya, maka bila dia (istrinya) sudah suci lalu dia berkehendak (untuk menceraikannya), maka silakan dia menceraikannya”, (Muttafaq 'alaihi, diriwayatkan oleh al-Bukhari, no. 5252 dan Muslim no. 1471$10)$.

\section{Ijmak}

Umat Islam telah sepakat dan kiyas juga menetapkan bahwa apabila pernikahan menjadi sempurna dengan akad untuk mencapai banyak kemaslahatan dan berbagai tujuan mulia, maka akad tersebut menjadi batal dengan perceraian karena maksudmaksud yang benar ${ }^{37}$.

\section{Macam-Macam Perceraian}

Para ulama sepakat bahwa perceraian (talak) itu ada dua macam: talak $b \bar{a}$ 'in dan

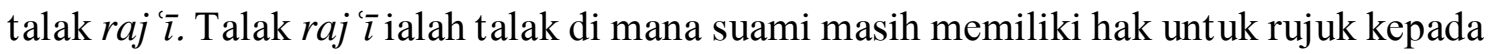
istri tanpa harus ada persetujuan istri. Di antara syaratnya ialah suami telah menggauli istrinya $^{38}$. Adapun talak $b \bar{a}$ 'in, mereka sepakat bahwa talak tersebut terdapat pada talak yang belum menggauli istri, karena bilangan talak dan karena adanya pengganti dalam khuluk $^{39}$.

\footnotetext{
${ }^{34}$ Kementrian Agama Republik Indonesia, Mushaf Tajwid dan Terjemah, h.37.

${ }^{35}$ Abdullạ̣ bin Muhammad al-Ṭayyār, dkk., al-Fiqh al-Muyassar (Cet. II; Riyāḍ: Madāru alWațini Lii an-Nasyr, 2012), h.

${ }^{36} \mathrm{Abu}$ 'Abdillah bin Muhammad bin Hanbal bin Hilāl bin Asad al-Syaibani, Musnad al-Imam Ahmad bin Hanbal, Jilid 9 (Cet. I; Bagdad: Muassasah al-Risalah, 1421 H/2001 M), h.361.

${ }^{37}$ Abdullah bin Aḥmad bin Muḥammad bin Qudāmah bin Miqdam Bin Naṣr bin Abdullah, Taysīr al- 'Allām Syarḥ 'Umdah al-Ahkām (Cet. I; Kairo: Dār al-Mugniy, 1427 H/2007 M). h

${ }^{38}$ Abū al-Walīd Muḥammad bin Aḥmad bin Muḥammad bin Aḥmad bin Rusyd al-Qurțubīy alAndalusīy, Bidā yah al-Mujtahid wa Nihā yah al-Muqtașid, Jilid 2 (Cet. III; Kairo: Dāru Ibnu al-Jauzi, 1425 H/2004 M), h.83.

${ }^{39}$ Abū al-Walīd Muḥammad bin Aḥmad bin Muhammad bin Aḥmad bin Rusyd al-Qurțubīy alAndalusīy, Bidāyah al-Mujtahid wa Nihāyah al-Muqtașid, h.83.
} 


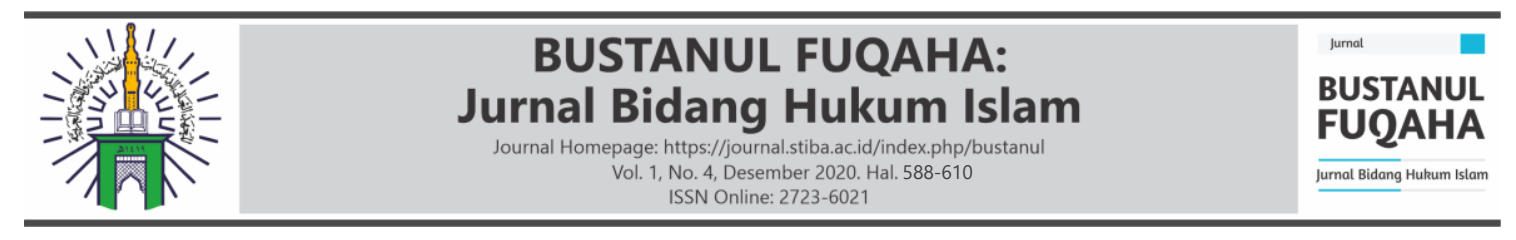

Adapun ditinjau dari segi waktu dijatuhkan talak itu, maka talak dibagi menjadi tiga macam, sebagai berikut ${ }^{40}$ : (1) Talak sunnī, yaitu talak yang dijatuhkan sesuai dengan tuntunan sunah. Dikatakan talak sunnī jika memenuhi empat syarat: (a) Istri yang ditalak sudah pernah digauli, (b) Istri dapat segera melakukan idah suci setelah ditalak, yaitu dalam keadaan suci dari haid, (c) Talak itu dijatuhkan ketika istri dalam keadaan suci, baik di permulaan, pertengahan maupun akhir suci, kendati beberapa saat lalu datang haid, (d) Suami tidak pernah menggauli istri selama masa suci di mana talak itu dijatuhkan; (2) Talak bid $\bar{\imath}$, yaitu talak yang dijatuhkan tidak sesuai atau bertentangan dengan tunt unan sunnah, tidak memenuhi syarat-syarat talak sunnī. Termasuk takal bid' $\bar{\imath}$ ialah: (a) Talak yang dijatuhkan terhadap istri pada waktu haid (menstruasi), baik di permulaan haid maupun di pertengahannya, (b) Talak yang dijatuhkan terhadap istri dalam keadaan suci tetapi pernah digauli oleh suaminya dalam keadaan suci dimaksud; (3) Talak lā sunn̄̄ wa lā bid'ī, yaitu talak yang tidak termasuk kategori talak sunnī dan tidak termasuk talak bid'í, yaitu: (a) Talak yang dijatuhkan terhadap istri yang belum pernah digauli, (b) Talak yang dijatuhkan terhadap istri yang belum pernah haid, atau istri yang telah lepas haid, (c) Talak yang dijatuhkan terhadap istri yang sedang hamil.

\section{Hikmah Disyariatkannya Perceraian}

Allah swt. mensyariatkan pernikahan untuk membangun mahligai rumah tangga yang bahagia, terbangun atas dasar cinta kasih antara kedua mempelai, dan kasih sayang antara kedua belah pihak, serta untuk mendapatkan keturunan dan menyalurkan nafsu seksual. Bila kebaikan sudah tidak ada dalam rumah tangga, niat dan janji antara keduanya telah pudar disebabkan perangai buruk dari salah satu pihak atau faktor-faktor lain penyebab perpecahan di antara keduanya, maka dalam kondisi seperti ini talak disyariatkan sebagai rahmat dan jalan keluar bagi keduanya ${ }^{41}$.

Talak disyariatkan karena di dalamnya terkandung solusi untuk menangani masalah suami istri manakala diperlukan, khususnya ketika tidak ada keharmonisan dan timbulnya kebencian yang karenanya membuat kedua belah pihak tidak mampu menegakkan batasan-batasan Allah dalam melangsungkan kehidupan rumah tangga, dan talak dengan alasan tersebut ialah salah satu bukti dari kebaikan Islam ${ }^{42}$.

Hal ini berbeda jauh dengan kaum Yahudi dan kaum musyrikin yang biasa menceraikan dan merujuk tanpa ada masa idah dan batasan. Jauh berbeda dengan kaum Nasrani yang tidak membolehkan talak, sehingga istri menjadi belenggu di leher suaminya meskipun di antara mereka berdua tidak terwujud maslahat pernikahan. Oleh karena itu, negara-negara Eropa dan Amerika menetapkan adanya hukum talak, karena

\footnotetext{
${ }^{40}$ Abd. Rahman Ghazaly, Fiqh Munākahāt, Jilid 1 (Cet. II; Jakarta: Kencana Predana Media Group, 2006), h.183-194.

${ }^{41}$ Tim Ulin Nuha Ma’had Aly al-Nur, Fikih Munā kahāt (Cet. I, Solo: Kiswah Media 2018), h.157.

${ }^{42}$ Abdullah bin Muḥammad al-Ṭayyār, dkk., al-Fiqh al-Muyassar (Cet. II; Riyāḍ: Madāru alWațini Lii an-Nasyr, 2012), h.91.
} 


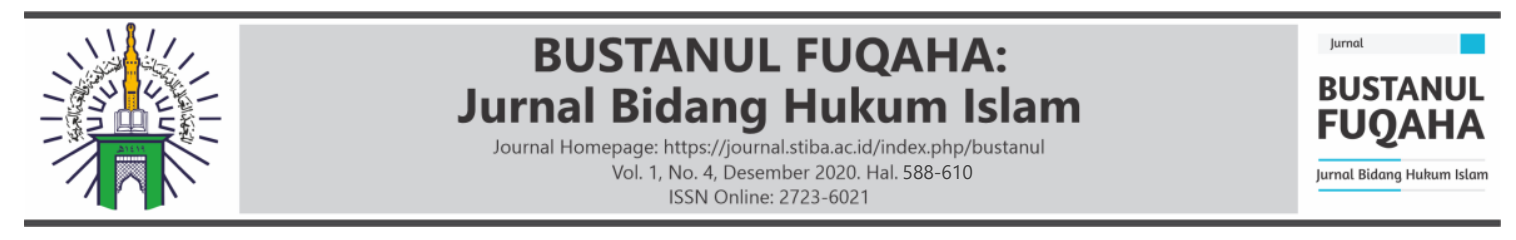

mereka melihat berbagai kemaslahatan dan manfaat yang terkandung di dalamnya, sesungguhnya Allah Maha Bijaksana lagi Maha Mengetahui ${ }^{43}$.

\section{Idah Wanita Hamil dan Idah Wanita Sebelum Berjimak}

Telah dikemukakan sebelumnya bahwa idah itu terbagi menjadi beberapa macam, namun yang perlu dijelaskan dalam pembahasan ini lebih mengarah kepada idah bagi wanita yang diceraikan dalam kondisi hamil dan idah bagi wanita yang diceraikan sebelum berjimak.

\section{Idah Wanita yang Diceraikan dalam Kondisi Hamil}

Idah wanita hamil berakhir setelah persalinan, baik ditalak atau ditinggal mati suami. Hal ini berdasarkan firman Allah 'Azza wa Jalla: ${ }^{44}$

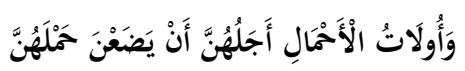

Terjemahnya:

"Dan wanita-Wanita yang hamil, waktu idah mereka itu ialah sampai mereka melahirkan kandungannya..." (Qs. Al-Ṭalāq/65: 4) ${ }^{45}$.

Untuk itu, tujuan dari masa idah ini ialah mengosongkan rahim dan itu tercapai dengan melahirkan kandungannya. Pendapat mayoritas ulama dan para imam fatwa, wanita tersebut dibolehkan menikah setelah melahirkan, walaupun masih dalam masa nifas karena idahnya telah habis dengan melahirkan. Namun, suaminya yang kedua tidak boleh mendekatinya kecuali setelah istrinya suci ${ }^{46}$. Adapun mengenai kapan wanita hamil bisa menikah kembali, para ulama fikih berbeda pendapat dalam hal ini. Pendapat para ulama antara lain:

\section{Pendapat Jumhur Ulama}

Pendapat pertama dari mayoritas ulama mengatakan bahwa seorang wanita boleh menikah lagi setelah kelahiran anaknya tanpa disyaratkan menunggu sampai selesai dari masa nifasnya. Namun, tetap harus diperhatikan ketika wanita tersebut memutuskan untuk menikah lagi, tidak boleh bercampur dengan suaminya sampai wanita tersebut suci. Pendapat ini didasarkan Firman Allah Ta'āla Qs. al-Baqarah/2: 222,

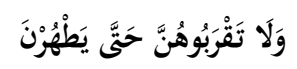

Terjemahnya:

\footnotetext{
${ }^{43}$ Abdullah bin Aḥmad bin Muḥammad bin Qudāmah bin Miqdam Bin Nașr bin Abdullah, Taysīr al- 'Allām Syarḥ 'Umdah al-Ahkām (Cet. I; Kairo: Dār al-Mugniy, 1427 H/2007 M). H.

${ }^{44}$ Abdu al-'Azīm bin Badawì bin Muhammad, al-Waj̄z fi Fiqh as-Sunnah (Cet. III; Mesir: Dār Ibnu Rajab, 1421 H/2001 M), h.329.

${ }^{45}$ Kementrian Agama Republik Indonesia, Mushaf Tajwid dan Terjemah (t. Cet; Solo: Penerbit Fatwa, 2017), h.558.

${ }^{46}$ Abu Mālik Kamāl bin al-Sayyid Sālim, Șạih Fiqh al-Sunnah, Jilid 3 (t. Cet; Mesir: alMaktabah al-Tawfĩqiyyah, 2003), h.325.
} 


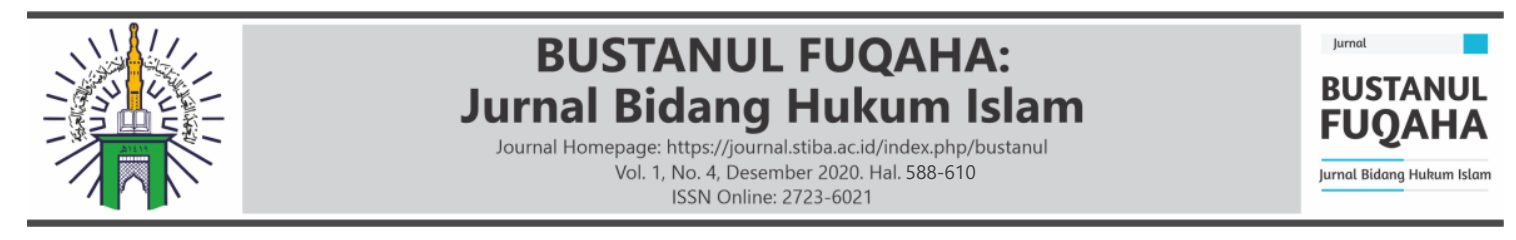

“Dan janganlah kamu dekati mereka sebelum mereka suci"47.

\section{Pendapat al-Hasan, al-Sya'bī, al-Nakha' i dan Hamad}

Pendapat kedua mengatakan bahwa wanita tersebut tidak boleh menikah dalam keadaan nifas sampai suci dari nifasnya. Pendapat ini didasarkan pada sebuah hadis,

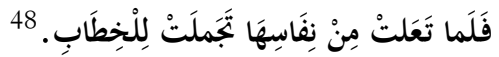

Artinya:

“Maka tatkala telah terangkat dari nifasnya, boleh ia dipinang" (HR. Al-Nasā’i). Demikianlah pendapat ulama mengenai kapan wanita hamil bisa menikah kembali ${ }^{49}$.

\section{Idah Wanita yang Diceraikan Sebelum Berjimak}

Pendapat yang disepakati para ulama bahwa wanita yang diceraikan (talak) sebelum terjadinya jimak maka boleh langsung menikah kembali dengan laki-laki lain setelah terjadinya talak ${ }^{50}$. Adapun pada pasal 153 Kompilasi Hukum Islam ayat (1) juga telah disebutkan bahwa: "Bagi seorang istri yang putus perkawinannya berlaku waktu tunggu atau idah, kecuali qobla al dukhūl dan perkawinannya putus bukan karena kematian suami" 51 . Istri yang dipisah oleh suaminya dalam keadaan hidup, seperti karena perceraian atau lainnya sebelum $d u k h \bar{u} l$ dengannya, tidak ada idah bagi istrinya itu. Hal itu berdasarkan firman Allah swt. ${ }^{52}$,

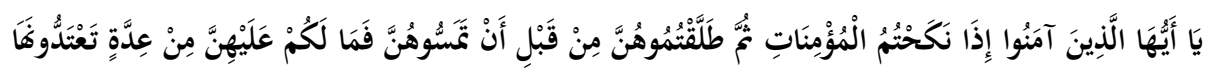

Terjemahnya:

"Hai orang-orang yang beriman, apabila kamu menikahi wanita-wanita yang beriman, kemudian kamu ceraikan mereka sebelum kamu mencampurinya maka sekali-sekali tidak wajib atas mereka idah bagimu yang kamu minta menyempurnakannya”" (Qs. al-Aḥzāb/33: 49) 53 .

Di dalam sebuah literatur fikih klasik, Tausyị̣̣ 'alā Fatḥi al-Qan̄̄b al-Muj̄̄b juga dijelaskan bahwa wanita yang diceraikan sebelum hubungan intim tidak memiliki masa

${ }^{47}$ Kementrian Agama Republik Indonesia, Mushaf Tajwid dan Terjemah (t. Cet; Solo: Penerbit Fatwa, 2017), h.35.

${ }^{48}$ Al-Nasa'i, 6/195.

${ }^{49}$ Vivi Kurniawati, Kupas Habis Hukum Idah Wanita (3) (Cet.I; Jakarta: Rumah Fikih Publishing, 2019), h.25.

${ }^{50} \mathrm{Abu}$ Mālik Kamāl bin al-Sayyid Sālim, Sahih Fiqh al-Sunnah, Jilid 3 (t. Cet; Mesir: alMaktabah al-Tawfĩqiyyah, 2003), h.323.

${ }^{51}$ Mohd. Idris Ramulyo, Hukum Perkawinan Islam (Cet. IV: Jakarta; PT Bumi Aksara, 2002), h.162.

${ }^{52}$ Ṣalih bin Fauzan bin Abdullah al-Fauzan, al-Mulakhaș al-Fiqhīy (Cet. I; Riyaḍ: Dār al-Așimah, 1423 H), h.244.

${ }^{53}$ Kementrian Agama Republik Indonesia, Mushaf Tajwid dan Terjemah (t. Cet; Solo: Penerbit Fatwa, 2017), h.424. 


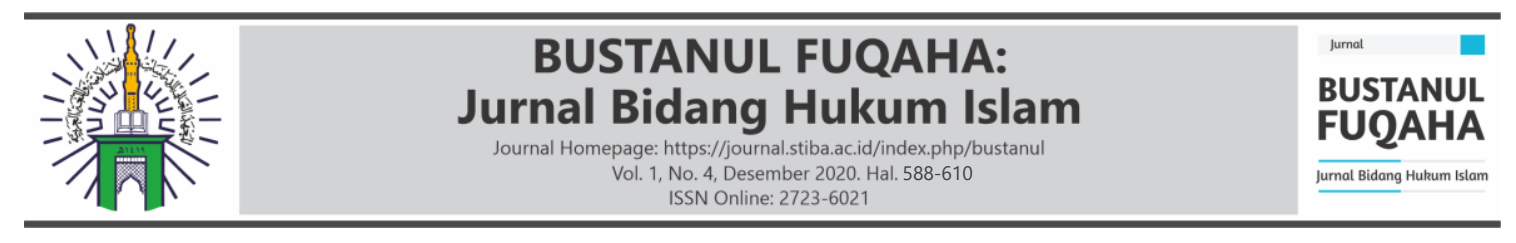

idah, baik suami telah berhubungan badan dengan selain farji atau tidak ${ }^{54}$. Sedangkan Imam Taqiyuddin Abu Bakar bin Muhammad al-Ḥusaini di dalam karyanya, Kifãyah alAkhyār, menyatakan bahwa wanita yang dicerai sebelum melakukan hubungan intim, jika tidak pernah berkhalwat (berduaan), maka tidak ada masa idah atas dirinya tanpa ada pro dan kontra bahkan telah disepakati (para ulama). Namun, jika wanita tersebut dicerai setelah berkhalwat, baik suami bersetubuh dengan selain farji atau tidak, maka ada dua pendapat dan pendapat yang paling kuat, yaitu yang menyatakan tidak ada idah at as dirinya ${ }^{55}$. Hal ini mengacu pada firman Allah swt. Qs. al-Aḥzāb/33:49, sebagaimana telah disebutkan sebelumnya. Sebagaian pendapat menyatakan wajib karena mengacu pada pernyataan 'Umar dan 'Alī, "Ketika pintu telah dikunci dan penutup telah diturunkan, maka wajib baginya maskawin yang sempurna dan wajib atas dirinya idah".

Dari pemaparan di atas, dapat diketahui bahwa istri yang belum pernah dijimak lalu dicerai, maka ia tidak memiliki masa idah. Namun, jika telah berduaan (berkhalwat) baik telah melakukan hubungan badan dengan memanfaatkan anggota tubuh selain farji atau tidak, maka ada dua pendapat: ${ }^{56}$ (1) Pendapat yang menyatakan tidak ada masa idah; (2) Pendapat yang menyatakan memiliki masa idah.

\section{Nikah Hamil dalam Praktik Hukum Positif dan Hukum Islam serta Idah Perceraiannya Pernikahan Wanita Hamil dalam Praktik Hukum Positif Indonesia}

Dalam pandangan sosiologis, wanita yang hamil sebelum menikah termasuk aib bagi dirinya dan keluarganya. Oleh karena itu, untuk menutupi aib tersebut wanita itu harus segera dikawinkan. Selain untuk menutupi aib, hal ini juga untuk menyelamatkan status anak yang dikandungnya. Sebagaimana disebutkan dalam Pasal 42 UU No. 1 Tentang Perkawinan: "Anak yang sah adalah anak yang dilahirkan dalam atau sebagai perkawinan yang sah" 57 . Adapun mengenai wanita hamil di luar nikah dalam Kompilasi Hukum Islam (KHI) pada pasal 53 tentang Kawin Hamil disebutkan: ${ }^{58}$ (1) Seorang wanita hamil di luar nikah dapat dikawinkan dengan pria yang menghamilinya; (2) Perkawinan dengan wanita hamil yang disebut pada ayat (1) dapat dilangsungkan tanpa menunggu lebih dahulu kelahiran anaknya; (3) Dengan dilangsungkannya perkawinan

\footnotetext{
${ }^{54}$ Syamsuddin Abu Abdillah Muhammad bin Qasim al-Ghazīy, Tausyih ‘alā Fathi al-Qan̄̄b alMuj̄b (t. Cet; Beirut: Dār al-Kutub al-Islāmiyyah, ), h.354.

${ }^{55}$ Taqiyuddin Abu Bakar bin Muhammad al-Ḥusaini al-Dimasyqīy al-Syāfi'ìy, Kifãyah alAkhyār fiy Hilli Gayah al-Ikhtisār , Jilid 1 (t. Cet; t.t.: Dār al-Minhaj, 2008), h.426.

${ }^{56}$ Abdul Malik,"Idah Istri yang Belum Pernah Dijimak, Tanya Jawab Seputar Idah, https://web.facebook.com/notes/majelis-talim-tanah-merah-mttm/doc_1422-idah-istri-yang-belumpernah-di-jima/1961948840685333/?_rdc=1\&_rdr (Diakses pada tanggal 25 April 2020).

${ }^{57}$ Tim Redaksi Nuansa Aulia, Kompilasi Hukum Islam (Cet. VII; Bandung: CV. Nuansa Aulia, 2017), h.

${ }^{58}$ Tim Redaksi Nuansa Aulia, Kompilasi Hukum Islam (Cet. VII; Bandung: CV. Nuansa Aulia, 2017), h.
} 


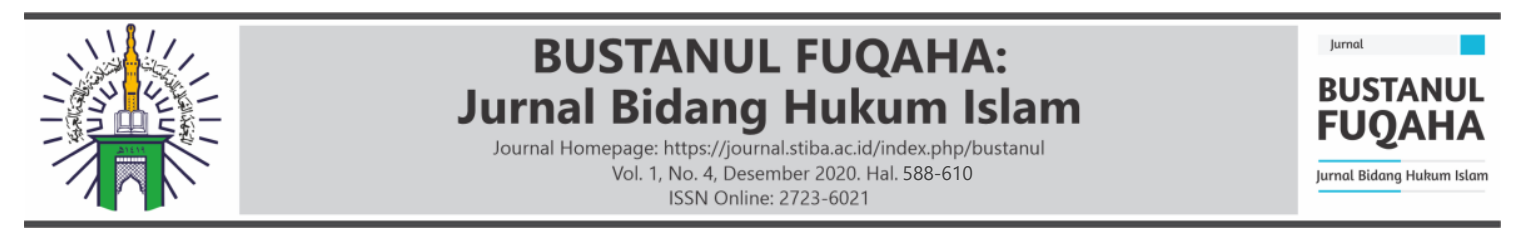

pada saat wanita hamil, tidak diperlukan perkawinan ulang setelah anak yang dikandung lahir.

Dari pasal tersebut disimpulkan bahwa pasal $53 \mathrm{KHI}$ tidak mengatur secara eksplisit bolehnya wanita hamil di luar nikah, dinikahkan dengan laki-laki selain yang menghamilinya. Tetapi secara tidak langsung menunjukkan bolehnya menikahi wanita hamil tersebut oleh laki-laki yang menghamilinya atau laki-laki selain yang menghamilinya. Adapun norma hukum yang digunakan pada pasal tersebut bersifat kebolehan (menggunakan kata 'dapat'), artinya tidak mutlak wanita tersebut harus dinikahi oleh laki-laki yang menghamilinya.

\section{Pandangan Ulama tentang Menikahi Wanita Hamil Akibat Zina, serta Masa Idahnya}

Mengenai hukum menikahi wanita akibat zina, terdapat perbedaan pendapat di kalangan para ulama. Ada yang pro terhadap masalah ini dan ada pula yang kontra. Sebagian ulama mengatakan bahwa menikahi wanita tersebut dinilai sah dan sebagian ulama lainnya melarang hal ini. Menurut Ibnu Rusyd, perbedaan pendapat ulama tersebut dikarenakan adanya perbedaan dalam memahami kalimat larangan dalam ayat,

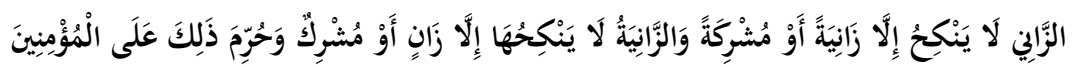

Terjemahnya:

"Pezina laki-laki tidak boleh menikah kecuali dengan pezina perempuan, atau dengan perempuan musyrik; dan pezina perempuan tidak boleh menikah kecuali dengan pezina laki-laki atau dengan laki-laki musyrik; dan yang demikian itu diharamkan bagi orang-orang mukmin" (Qs. al-Nūr/24:3) ${ }^{59}$.

Menurut Sayyid Sābiq, dibolehkan mengawini wanita pezina yang telah bertaubat, karena Allah swt. menerima taubat hamba-Nya yang telah bertaubat dan memasukkannya ke dalam golongan hamba-Nya yang salih ${ }^{60}$. Pendapat ini salah satu pendapat yang pro terhadap masalah pernikahan akibat zina.

Pada dasarnya, wanita baru boleh menikah kembali jika sudah berada dalam masa idah (masa tunggu setelah bercerai dengan suami). Salah satu macam idah adalah idah bagi wanita hamil, yaitu idahnya setelah melahirkan kandungan. Lalu bagaimana hukumnya jika hamil akibat zina (hamil di luar nikah)?, apakah harus menunggu melahirkan baru boleh menikah seperti idah wanita hamil ${ }^{61}$. Hal inilah yang menjadi inti permasalahan, karena hukum idah itu ada dan berlaku bagi orang yang sudah

\footnotetext{
${ }^{59}$ Kementrian Agama Republik Indonesia, Mushaf Tajwid dan Terjemah (t. Cet; Solo: Penerbit Fatwa, 2017), h.350.

${ }^{60}$ Sayyid Sabiq, Fiqh al-Sunnah (t. Cet; Beirut: Dār al-Fikr, 1983), h.

${ }^{61}$ Agung Nugroho, "Hukum Menikahi Wanita Hamil Karena Zina Dalam Islam”, Megapolitan Pos, https://www.megapolitanpos.com/index.php?/detail/923/hukum-menikah-wanita-hamil-karenazina-dalam-islam (Diakses pada tanggal 25 April 2020) .
} 


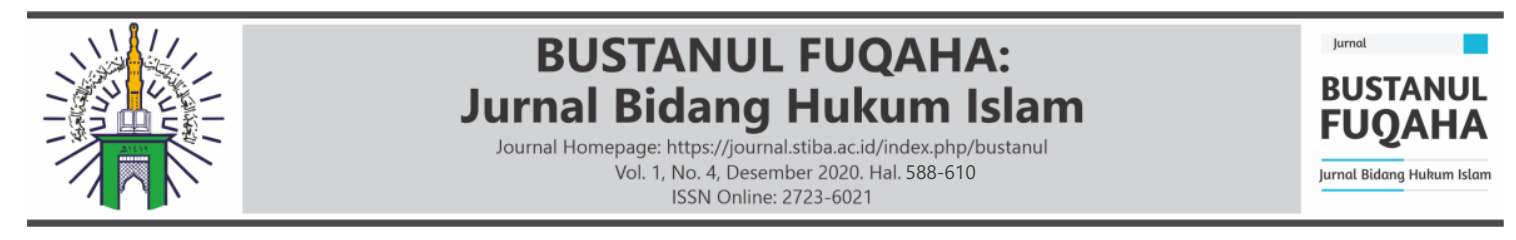

menikah, adapun bagi wanita yang hamil di luar nikah ada atau tidak adanya idah masih diperselisihkan oleh para ulama.

Berikut pendapat ulama mengenai idah wanita yang jatuh dalam perkara zina (hamil di luar nikah), para ulama memiliki tiga pendapat: ${ }^{62}$ (1) Pendapat pertama, tidak ada idah atasnya. Ini mazhab Abu Hanifah, al-Tsauri dan al-Syāfi iyyah, baik wanita tersebut hamil atau tidak. Pendapat ini juga diriwayatkan dari Abu Bakar, Umar dan Ali. Karena idah disyariatkan untuk memelihara nasab, sedangkan zina tidak berkaitan dengan kepastian nasab, maka tidak diwajibkan idah; (2) Pendapat kedua, idahnya seperti wanita yang ditalak (tiga qurū 'atau tiga masa haid). Inilah pendapat yang dianut dalam mazhab Malikiyah dan Hanbaliyah. Ini juga pendapat al-Hasan dan al-Nakha'i. Karena perzinaan ialah persetubuhan yang berpengaruh terhadap rahim, maka wajib idah darinya. Alasan lainnya, karena wanita ini ialah wanita merdeka, maka wajib ber-istibrā ', (mengosongkan rahim) dengan idah sempurna, seperti halnya wanita yang digauli karena syubhat; (3) Pendapat ketiga, wanita tersebut ber-istibrā' dengan satu kali haid. Ini merupakan pendapat Malik dan satu riwayat dari Ahmad yang didukung oleh Syaikhul Islam sebagaimana pada perkara wanita yang digauli dengan syubhat. Menurut Abu Mālik Kamāl bin al-Sayyid Sālim dalam bukunya Ș ạ ih Fiqh al-Sunnah, pendapat ketiga ialah pendapat yang lebih mendekati kebenaran ${ }^{63}$.

Perbedaan pendapat di kalangan ulama tentang hukum pernikahan wanita hamil akibat zina bersumber dari perbedaan memahami dalil. Adapun secara rinci mengenai pendapat ulama berkaitan masalah ini akan dijelaskan pada poin berikut:

\section{Pendapat Mazhab Malikiyyah}

Menurut mazhab Malikiyyah, tidak membolehkan perkawinan wanita hamil akibat zina dengan laki-laki, yang bukan menghamilinya, dan bahwa mazhab Maliki mengambil makna umum dari dalil-dalil yang dijadikan dasar pendapatnya. Mazhab Maliki mendasarkan pendapatnya pada Firman Allah Ta'āla surah al-Ṭalāq/65: 4,

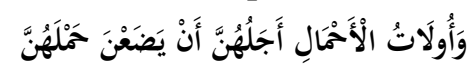

Terjemahnya:

"Dan wanita-Wanita yang hamil, waktu idah mereka itu ialah sampai mereka melahirkan kandungannya"64.

\footnotetext{
${ }^{62}$ Abu Muhammad Abdullah ibnu Ahmad ibnu Muhammad ibnu Qudāmah al-Maqdisīy alJammā'îlīy al-Dimasyqīy al-Hanbalīy, al-Mugnīy, Jilid 9 (Cet. III; Riyaḍ: Dār 'Ālam al-Kutub, 1417 H/1997 M), h.79.

${ }^{63}$ Abu Mālik Kamāl bin al-Sayyid Sālim, Șạih Fiqh al-Sunnah, Jilid 3 (t. Cet; Mesir: alMaktabah al-Tawfiqiyyah, 2003), h. 324.

${ }^{64}$ Kementrian Agama Republik Indonesia, Mushaf Tajwid dan Terjemah (t. Cet; Solo: Penerbit Fatwa, 2017), h.558.
} 


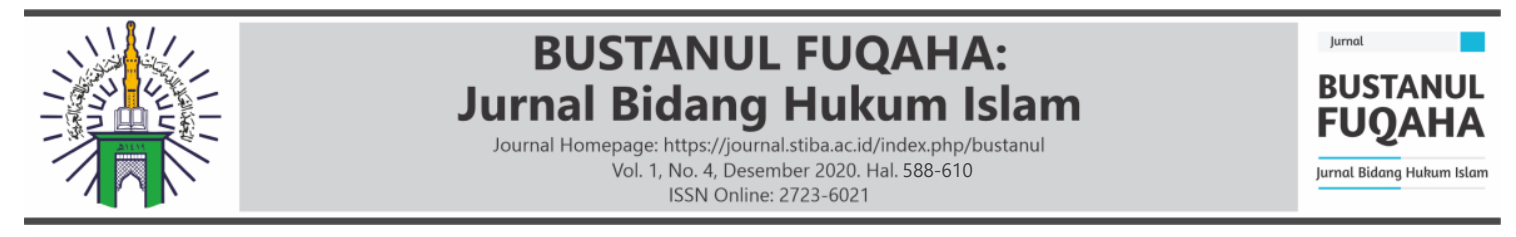

Ayat tersebut mengandung makna bahwa wanita hamil itu mempunyai masa idah, yaitu hingga melahirkan anaknya. Jadi, mazhab Maliki beranggapan bahwa wanitawanita hamil akibat zina juga mempunyai masa idah berdasarkan keumuman ayat tersebut. Dalam ayat ini tidak mempertimbangkan fakta yang menyebabkan kehamilan wanita tersebut, baik hamil itu melalui hubungan suami istri yang sah, hamil akibat perzinaan, hamil akibat perkosaan, bahkan hamil karena bayi tabung dan sebagainya. Inti dari permasalahan ini adalah karena adanya fakta kehamilan.

Adapun pendapat lainnya oleh Malik dan satu riwayat dari Ahmad yang didukung oleh Syaikhul Islam bahwa wanita yang jatuh dalam perkara zina maka idahnya disamakan dengan perkara wanita yang digauli karena syubhat yaitu dengan beristibrā ' dan menunggu satu kali haid. Berdasarkan hadis, Nabi saw. bersabda:

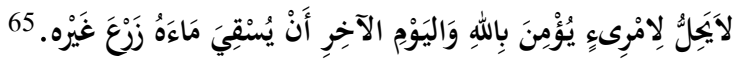

Artinya:

"Tidak halal bagi seseorang yang beriman kepada Allah dan hari akhir menyiram air pada tanaman orang lain”.

Ibnu al-Mulaqqan mengatakan: "Hadis ini sahih, telah diriwayatkan oleh Ahmad dalam musnadnya, Abu Dāud dan al-Tirmiżi dalam Sunan keduanya dari Ruwaifa' bin Tsabit al-Anșarì”66. Adapun Ibnu Hajar al-Haitamy membantah dalil tersebut dengan mengatakan bahwa Asbā $b$ al-wurū $d$ hadis tersebut untuk menjauhi menggauli wanita tawanan perang yang hamil, karena kandungannya terhormat, maka haram menggaulinya. Tidak sama halnya dengan kandungan karena zina, sesungguhnya tidak ada penghormatan baginya yang menghendaki kepada haram menggaulinya ${ }^{67}$.

Sebagian umat Islam berbeda pendapat dengan pendapat di atas, mereka mengatakan wanita yang hamil karena perbuatan zina tidak boleh dinikahkan, baik dengan laki-laki yang menghamilinya ataupun dengan laki-laki lain kecuali bila memenuhi dua syarat, yaitu: ${ }^{68}$

a) Wanita dan laki-laki tersebut telah bertaubat dari perbuatan zinanya. Dalilnya adalah Firman Allah Ta'āla dalam al-Qur' an surah al-Nūr/24:3,

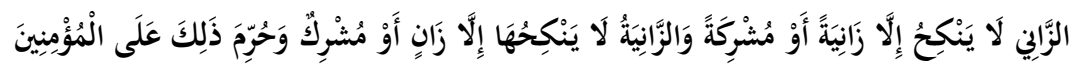

${ }^{65}$ Abu Daud, Sunan Abìy Daud, Jilid 1 (t. Cet; t.t.:Dār al-Fikrīy, t.th.), h.654.

${ }^{66}$ Ibnu al-Mulaqqan Sirāj al-Dīn Abū Hafị̣ 'Umar bin 'Alīy bin Ahmad al-Syafi'īy al-Miṣrīy, alBadru al-Munīr, Jilid 8 (Cet. I; Riyāḍ: Dār al-Hijrah līy al-Nasyr wa al-Tawzīy’, 1425 H-2004 M), h.214.

${ }^{67}$ Syiḥabuddin Abu al-'Abbās Ahmad bin Muhammad bin 'Alīy bin Hajar al-Haitamīy al-Sa' dīy al-Anșārīy, al-Fatā wā Al-Kubrā al-Fiqhiyyah, Jilid 4 (t. Cet; Beirut: Dār al-Fikri, t.th.), h.94.

${ }^{68}$ Alizar Usman, "Nikah dengan Wanita Hamil Karena Zina”, Artikel, http://kitabkuneng.blogspot.com/2011/12/nikah-dengan-wanita-hamil-karena-zina_02.html (Diakses pada tanggal 25 April 2020) 


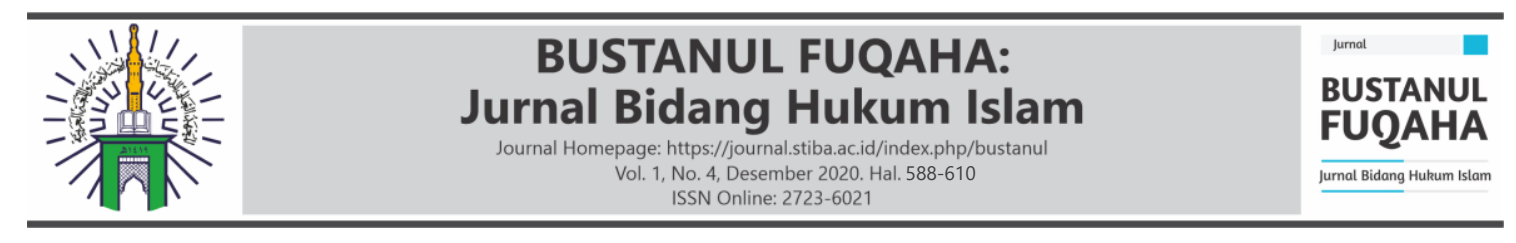

Terjemahnya:

"Pezina laki-laki tidak boleh menikah kecuali dengan pezina perempuan, atau dengan perempuan musyrik; dan pezina perempuan tidak boleh menikah kecuali dengan pezina laki-laki atau dengan laki-laki musyrik; dan yang demikian itu diharamkan bagi orang-orang mukmin"69.

Mereka mengatakan bahwa ayat ini menjadi dalil tidak boleh menikah dengan orang-orang yang zahir padanya perbuatan zina ${ }^{70}$.

Adapun keterangan yang disampaikan oleh Imam al-Syāfi' $1 \overline{1}$ dalam al-Umm, setelah menyebut beberapa penafsiran yang disampaikan oleh ahli tafsir mengenai tafsir ayat di atas, mengatakan bahwa pendapat yang dikemukakan oleh Sa'ĩd bin alMusayyab, salah seorang ahli tafsir dari Tabi'in merupakan pendapat yang didukung oleh al-Kitāb dan al-Sunnah. Pendapat Sa īd al-Musayyab tersebut adalah. "Ayat di atas sudah dinasakh oleh ayat":

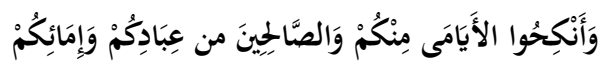

Terjemahnya:

Dan nikahkanlah orang-orang yang masih membujang di antara kamu, dan juga orang-orang yang layak (menikah) dari hamba-hamba sahayamu yang laki-laki dan perempuan.

Hal ini dikarenakan pezina itu termasuk dalam kelompok "al-ayāmō" (yang belum nikah) dari kamu muslimin ${ }^{71}$. Untuk itu, ayat di atas tidak dapat dijadikan sebagai hujah penetapan suatu hukum ${ }^{72}$.

b) Harus beristibra'(menunggu kosongnya rahim) dengan satu kali haid bila wanita tidak hamil. Adapun bila hamil, maka sampai wanita tersebut melahirkan kandungannya. Dalilnya adalah sabda Rasulullah saw.:

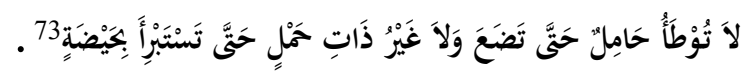

Artinya:

"Tidak boleh digauli yang sedang hamil sampai ia melahirkan, dan (tidak boleh digauli) yang tidak hamil sampai dia beristibra' dengan satu kali haid' (H.R. Abu Daud)

\footnotetext{
${ }^{69}$ Kementrian Agama Republik Indonesia, Mushaf Tajwid dan Terjemah (t. Cet; Solo: Penerbit Fatwa, 2017), h.350.

${ }^{70}$ Muhammad bin al-'Assimaini, Tukmalah Fatā wā al-Mauqa', h.1.

${ }^{71} \mathrm{Abu}$ 'Abdillah Muhammad bin Idrīs al-Syafi'’̄, al-Um, Jilid 5 (Cet. II; Beirut: Dār al-Fikri , 1403 H-1983 M), h.148.

${ }^{72}$ Alizar Usman, "Nikah dengan Wanita Hamil Karena Zina", Artikel, http://kitabkuneng.blogspot.com/2011/12/nikah-dengan-wanita-hamil-karena-zina_02.html (Diakses pada tanggal 25 April 2020)

${ }^{73}$ Abū Daud, Sunan Abī Daud, Jilid 11 (t. Cet; t.t.:Dār al-Fikrīy, t.th.), h.213.
} 


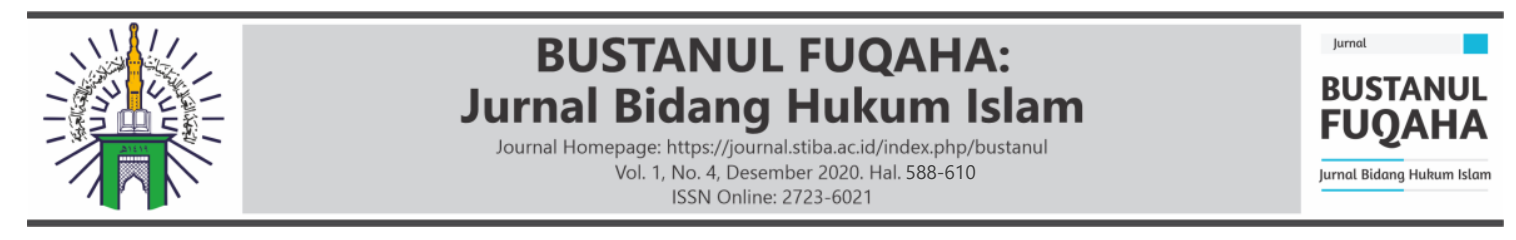

Hadis ini juga diriwayatkan oleh al-Hakìm, beliau mengatakan: "Hadis ini sahih atas syarat Muslim"74. Dalam hadis di atas Rasulullah saw. melarang menggauli budak (hasil pembagian) tawanan perang yang sedang hamil sampai melahirkan. Adapun yang tidak hamil ditunggu satu kali haid, padahal budak itu sudah menjadi miliknya ${ }^{75}$. Hadis tersebut juga membicarakan masalah perempuan tawanan perang yang sedang hamil menjadi budak karena merupakan rampasan perang, buktinya, ujung hadis ini menjelaskan bahwa perempuan yang tidak hamil ditandai dengan istibr $\bar{a}$ ' (menunggu masa tertentu untuk memastikan kosong rahim seorang budak perempuan) hanya dengan satu kali haid. Sedangkan istibrā 'hanya dengan satu kali haid hanya berlaku pada budak, tidak berlaku pada perempuan merdeka. Perempuan-perempuan tawanan tersebut tidak dapat disamakan dengan kasus seorang perempuan yang hamil karena zina. Kehamilan pada perempuan tawanan perang berlaku istibrā', karena kehamilan perempuan tersebut adalah dikarenakan suaminya. Oleh karena itu, wajib menunggu sampai melahirkan. Berbeda halnya dengan perempuan yang hamil karena zina, kehamilannya itu tidak dihormati. Oleh karena itu, tidak ada kewajiban untuk idah ${ }^{76}$.

Menurut pendapat yang melarang hal ini, jika dua syarat ini telah terpenuhi, maka wanita tersebut baru boleh dinikahi. Wanita yang telah dizinai jika wanita tersebut betul-betul telah bertaubat pada Allah dan telah melakukan istibrā' (membuktikan kosongnya rahim dari mani hasil zina), maka ketika dua syarat ini terpenuhi boleh menikahi dirinya dengan tujuan apa pun. Jika tidak terpenuhi dua syarat ini, maka tidak boleh menikahinya walaupun dengan maksud untuk menutupi aibnya di masyarakat. ${ }^{77}$

Simpulannya, konsekuensi dari menikahi wanita hamil adalah nikahnya tidak sah, baik yang menikahinya adalah laki-laki yang menzinainya atau laki-laki lainnya. Ini merupakan pendapat yang dipilih oleh para ulama Hambaliyyah dan Malikiyyah. Bila seseorang tetap menikahkan putrinya yang telah berzina tanpa istibrō ' terlebih dahulu, sedangkan dia tahu bahwa pernikahan itu tidak boleh dan laki-laki serta wanita juga mengetahui bahwa itu adalah haram, maka pernikahannya itu tidak sah. Bila keduanya melakukan hubungan badan maka itu adalah zina ${ }^{78}$. Dia harus taubat dan pernikahannya harus diulangi, bila telah selesai istibrāa' dengan satu kali haidh dari hubungan badan yang terakhir atau setelah melahirkan.

${ }^{74}$ Ibnu al-Mulaqqan Sirāj al-Dīn Abū Hafị̣ 'Umar bin 'Alī bin Ahmad al-Syafi'ī al-Mișrī, alBadru al-Munīr, Jilid 3 (Cet. I; Riyāḍ: Dār al-Hijrah līy al-Nasyr wa al-Tawzīy’, 1425 H-2004 M), h.142.

${ }^{75}$ Alizar Usman, "Nikah dengan Wanita Hamil Karena Zina", Artikel, http://kitabkuneng.blogspot.com/2011/12/nikah-dengan-wanita-hamil-karena-zina_02.html (Diakses pada tanggal 25 April 2020)

${ }^{76}$ Alizar Usman, "Nikah dengan Wanita Hamil Karena Zina”, Artikel, http://kitabkuneng.blogspot.com/2011/12/nikah-dengan-wanita-hamil-karena-zina_02.html (Diakses pada tanggal 25 April 2020)

${ }^{77}$ Fatwa al-Syabakah al-Islamiyah, 2/4764

${ }^{78}$ Fatwa al-Syabakah al-Islamiyah, 2/4764 


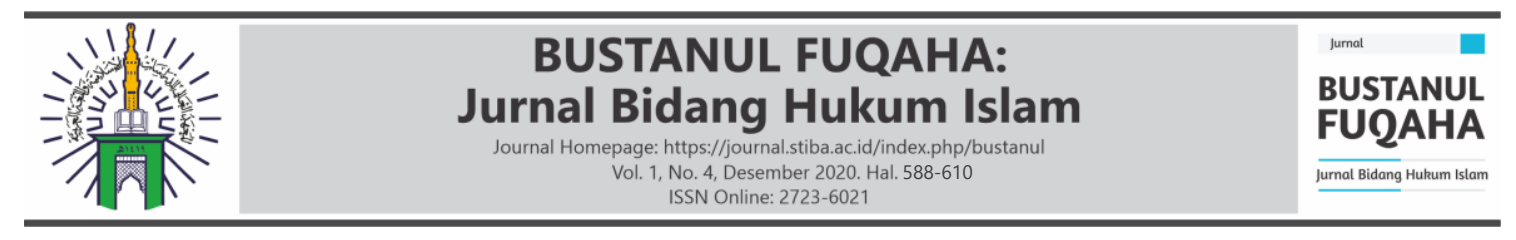

\section{Pendapat Mazhab Syafii}

Pendapat ulama mazhab Syafi'iyyah bahwa wanita hamil akibat zina tidak mempunyai idah. Hamil yang wajib idah hanyalah hamilnya wanita yang ditalak atau ditinggal mati suaminya. Berikut perkataan beberapa ulama Syafi'iyyah yang menyatakan bahwa tidak ada idah bagi wanita hamil akibat zina, antara lain ${ }^{79}$ :

(a) Dalam al-Majmū' Syarh al-Muhadzdzab disebutkan: "Apabila seorang wanita berzina, maka tidak wajib atasnya ber-idah, baik dalam keadaan tidak hamil maupun hamil, maka boleh bagi wanita pezina dan lainnya yang bukan menzinainya melakukan akad nikah atasnya dan jika wanita tersebut hamil karena zina, maka makruh menikahinya sebelum melahirkan anaknya" 80 ;

(b) Sayyid 'Abdullah bin 'Umar dan Syaikh Muhammad al-Asykhar al-Yamany mengatakan: "Wanita hamil karena zina boleh menikah, baik oleh pezina itu sendiri maupun lainnya dan boleh disetubuhi ketika itu tetapi makruh"81;

(c) Berkata Ibnu Hajar Haitamy: "Adapun hukum nikah wanita hamil karena zina, terjadi khilaf yang tersebar di kalangan imam-imam dan lainnya. Pendapat ini juga telah dikatakan oleh Abu Hanifah karena wanita itu tidak dalam nikah dan tidak juga dalam idah orang lain. Dari Malik ada sebuah perkataan yang menyatakan sebaliknya"82;

(d) Adapun hukum bersetubuh dengannya setelah dinikahkan sebelum melahirkan adalah boleh berdasarkan pendapat yang dibenarkan oleh Imam Nawawi dan al-Rafí i: "Sesungguhnya tidak ada penghormatan bagi kandungan zina, kalau terlaramg menyetubuhinya, maka terlarang juga menikahinya seperti bersetubuh dengan syubhat"83.

Berdasarkan boleh menyetubuhinya maka hukumnya adalah makruh, karena keluar dari khilaf ulama yang mengharamkannya. ${ }^{84}$ Adapun dalil yang dipegang oleh mazhab Syafi'iyyah, yang membolehkan menikahi wanita hamil baik oleh pezinanya atau yang bukan menzinainya berdasarkan Firman Allah Ta'āla ayat 24 surah al-Nisā',

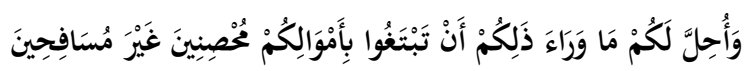

${ }^{79}$ Alizar Usman, "Nikah dengan Wanita Hamil Karena Zina", Artikel, http://kitabkuneng.blogspot.com/2011/12/nikah-dengan-wanita-hamil-karena-zina_02.html (Diakses pada tanggal 25 April 2020)

${ }^{80}$ Al-Nawawīy, Majmu’ Syarh al-Muhazzab (t. Cet; Beirut: Dār al-Fikr, 1997 M), h.242.

${ }^{81}$ Abdurrahman bin Muhammad bin Husain bin 'Umar Bā'lawīy, Bugyatu al-Mursyidin, Jilid 1 (Dār al-Fikr), h.201.

${ }^{82}$ Syiḥabuddin Abu al-'Abbās Ahmad bin Muhammad bin 'Alīy bin Hajar al-Haitamīy al-Sa' dīy al-Anșārīy, al-Fatā wā Al-Kubrā al-Fiqhiyyah, Jilid 4 (t. Cet; Beirut: Dār al-Fikri, t.th.), h.93-94.

${ }^{83}$ Syiḥabuddin Abu al-'Abbās Ahmad bin Muhammad bin 'Alīy bin Hajar al-Haitamīy al-Sa' dīy al-Anșārīy, al-Fatā wā Al-Kubrā al-Fiqhiyyah, h.94.

${ }^{84}$ Alizar Usman, "Nikah dengan Wanita Hamil Karena Zina”, Artikel, http://kitabkuneng.blogspot.com/2011/12/nikah-dengan-wanita-hamil-karena-zina_02.html (Diakses pada tanggal 25 April 2020) 


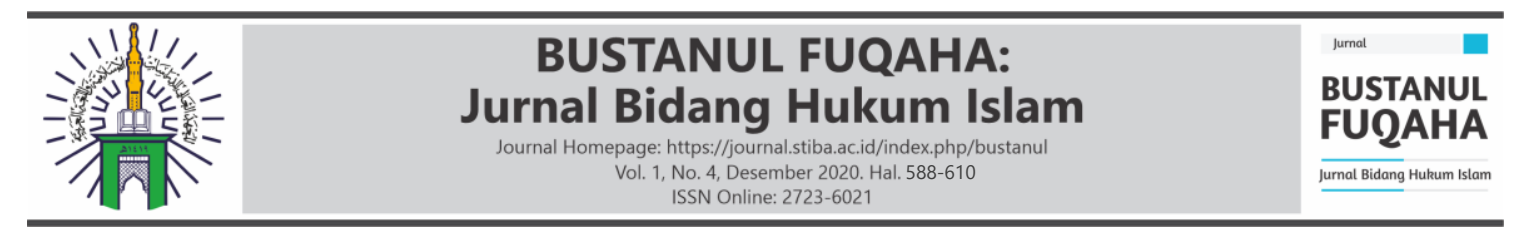

Terjemahnya:

"Dan dihalalkan bagi kamu selain yang demikian (yaitu) mencari istri-istri dengan hartamu untuk dikawini bukan untuk berzina"85.

Ayat tersebut mengisyaratkan bahwa wanita pezina baik yang hamil ataupun yang tidak hamil tidak disebutkan sebagai wanita-wanita yang haram untuk dinikahi sebagaimana yang disebutkan dalam Al-Qur'an surah al-Nisā' ayat 22 dan 23. Dengan demikian, menikahi wanita hamil akibat zina boleh dilakukan karena tercakup dalam pengertian ayat 24 yang menegaskan kehalalan menikahi wanita selain yang tersebut dalam ayat sebelumnya. Adapun perempuan yang hamil karena zina, maka termasuk dalam kategori mutlak perempuan yang dihalalkan untuk dinikahi pada ayat di atas. Sementara itu, tidak ada dalil atau ilat lain yang menunjukkan kepada haram menikahinya. Apabila dikatakan perempuan hamil karena zina itu ber-idah, ini juga tidak, disebabkan hamil karena zina tidak dihormati dalam agama, buktinya anak dalam kandungannya itu tidak dihubungkan nasabnya kepada laki-laki penzinanya ${ }^{86}$. Adapun dalam hadis, Nabi Șallallāhu 'alaihi wa Sallam bersabda:

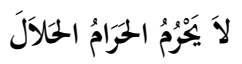

Artinya:

“Perbuatan haram tidak mengharamkan yang halal” (HR. al-Thabrany).

Al-Haitami mengatakan bahwa hadis ini diriwayatkan oleh al-Ṭabarānī dalam alAusat, namun dalam sanadnya ada 'Utsmān bin Abd. al-Raḥmān al-Zahri, sedangkan dia ini matrū $k^{87}$. Jalan pendalilannya adalah zina yang meyebabkan hamil adalah perbuatan haram. Oleh karena itu, zina tersebut tidak dapat mengharamkan perbuatan halal, yakni halal dinikahi perempuan oleh seorang laki-laki ${ }^{88}$. Imam al-Nawawī telah menyebut dua dalil di atas sebagai sebagian dalil yang membolehkan menikahi perempuan hamil karena zina dalam kitab beliau Majmū' Syaṛ al-Muhadzdzab ${ }^{89}$. Ada suatu kaidah fikih yang berbunyi:

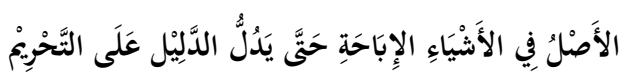

Artinya:

${ }^{85}$ Kementrian Agama Republik Indonesia, Mushaf Tajwid dan Terjemah (t. Cet; Solo: Penerbit Fatwa, 2017), h.82.

${ }^{86}$ Alizar Usman, "Nikah dengan Wanita Hamil Karena Zina", Artikel, http://kitabkuneng.blogspot.com/2011/12/nikah-dengan-wanita-hamil-karena-zina_02.html (Diakses pada tanggal 25 April 2020)

${ }^{87}$ Nur al-Dīn al-Haitsamīy, Majma’' al-Zawaid, Jilid 4 (t. Cet; Beirut: Dār al-Kitāb al- 'Arabīy, 2009), h.311.

${ }^{88}$ Alizar Usman, "Nikah dengan Wanita Hamil Karena Zina", Artikel, http://kitabkuneng.blogspot.com/2011/12/nikah-dengan-wanita-hamil-karena-zina_02.html (Diakses pada tanggal 25 April 2020)

${ }^{89}$ Al-Nawawīy, Majmu’ Syarh al-Muhazzab (t. Cet; Beirut: Dār al-Fikr, 1997 M), h.242. 


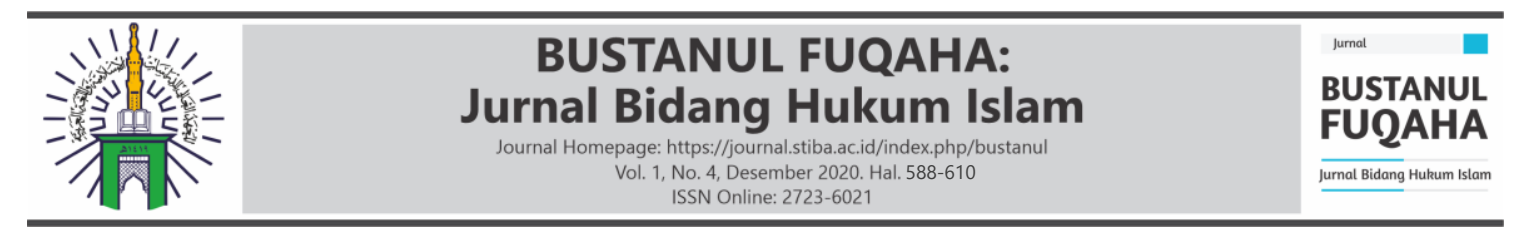

“Asal sesuatu adalah boleh sehingga ada dalil yang menunjukkan kepada keharamannya" $"$.

Oleh karena itu, tidak ada hal-hal yang menyebabkan haram atau tidak sah, maka hukumnya adalah boleh.

\section{KESIMPULAN}

Berdasarkan uraian di atas, dapat disimpulkan bahwa hukum idah dapat berbeda antara satu orang perempuan dengan perempuan lainnya, berdasarkan jenis perceraian atau proses terputusnya ikatan pernikahan, serta atas kondisi perempuan itu sendiri. Hukum idah cerai bagi perempuan yang sedang hamil, yaitu kelahiran anak yang dikandungnya juga dapat berlaku bagi perempuan yang dijatuhi talak, sedangkan dia dalam keadaan hamil akibat perbuatan zina.

\section{DAFTAR PUSTAKA}

Al-Qur'an al-Karim

Abdullah. Ibnu Qudamah. (2007). Taysīr al-'Allam Syarh 'Umdah al-Ahkam. Kairo: Dar al-Mugniy.

Abd. Rahman. Ghazaly. (2003). Fiqh Munakahat. Jakarta: Kencana Prenada Media Group.

Abdu al-Rahman. Ba'lawi. (t.th). Bugyatu al-Mursyidin. Beirut: Dar al-Fikr.

Abdu al-Rahman. al-Suyuti. (t.th). al-Asybah wa al-Naza'ir. Beirut: Dar al-'Alamiyyah. Abdullah. Ibnu Qudamah al-Maqdisi. (1997). al-Mugni. Riyad: Dar 'Alam al-Kutub.

Abu Bakar. al-Dimasyqi. (2008). Kifayah al-Akhyar fi Hilli Gayah al-Ikhtisar. Dar alMinhaj.

Abdullah. al-Tayyar. (2012). al-Fiqh al-Muyassar. Riyad: Madaru al-Watan li al-Nasyr. Ahmad. Al-Haitami. (t.th). al-Fatawa Al-Kubra. Beirut: Dar al-Fikri.

Arikunto. Suharsimi. (2013). Prosedur Penelitian Suatu Pendekatan Praktik. Jakarta: PT. Rineka Cipta.

Azwar. Hafid. (2011). Pandangan Hakim Dalam Memberikan Idah Bagi Perceraian Nikah Hamil Qabla al Dukhul, Studi Kasus di Pengadilan Agama Kabupaten Malang. Skripsi. Malang: Fakultas Syariah Universitas Maulana Malik Ibrahim Malang.

Basri. Cik Hasan. (2003). Model Penelitian Kitab Fikih. Bogor: Kencana.

Dahlan. Abdul Aziz. (1997). Ensiklopedi Hukum Islam. Jakarta: PT. Intermasa.

Indriantoro, Nur., \& Bambang Supomo. (2013). Metodologi Penelitian Bisnis untuk Akuntansi dan Manajemen. Yogyakarta: BPFE.

Kamal. Al-Sayyid. (2013). Sahih Fiqh al-Sunnah. Mesir: al-Maktabah al-Tawfiqiyyah.

\footnotetext{
${ }^{90}$ Jalāl al-Dīn 'Abdu al-Rahmān al-Suyuțīy, al-Asybāh wa al-Nazāîir (t. Cet; Beirut: Dār al'Alamiyyah, t.th.), h.43.
} 


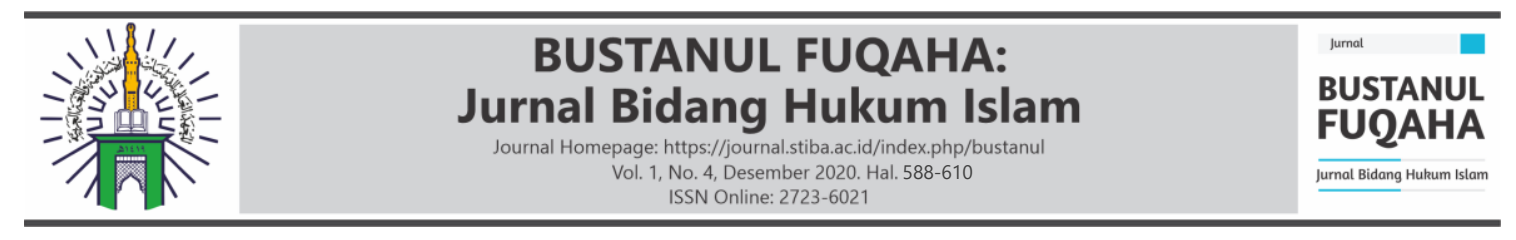

Kurniawati. Vivi. (2019). Kupas Habis Hukum Idah Wanita (3). Jakarta: Rumah Fikih Publishing.

Masyuri. (2008). Metodologi Penelitian. Bandung: Rafika Aditama.

Muhammad. al-Sabuni. (2017). Rawai'u al-Bayan Tafsir Ayati al-Ahkam Min AlQur'an. Lebanon: al-Maktabah al-'Asriyyah.

Muhammad. Ibnu Rusydi al-Qurtubi. (2004). Bidayah al-Mujtahid wa Nihayah alMuqtasid. Kairo: Dar al-Hadis.

Muhammad. Syams al-Din al-Ghazzi. (t.th). Fathu al-Qarib al-Mujib fi Syarhi Alfazh al-

Taqrib. Beirut: Dar al-Kutub al-Islamiyyah.

Muhammad. Badawi. (2001). al-Wajiz fi Fiqh as-Sunnah. Mesir: Dar Ibnu Rajab.

Mustafa. Ibrahim. (2011). al-Mu'jam al-Wasit. Mesir: Maktabah Kunuz al-Ma'rifah.

Nur al-Din. Al-Haitsamīy. (2009). Majma’ al-Zawaid wa Manba' al-Fawa'id. Beirut: Dar al-Kitab al-'Arabi.

Rahman, R. A. (2016). Konsep Keadilan dalam Alquran. NUKHBATUL'ULUM: Jurnal Bidang Kajian Islam, 2(1), 167-175.

Ramulyo. Mohd. Idris. (2002). Hukum Perkawinan Islam. Jakarta: PT. Bumi Aksara.

Sabiq. Sayyid. (1983). Fiqh al-Sunnah. Beirut: Dar al-Fikri.

Salih. al-Fauzan. (1423). al-Mulakhas al-Fiqhi. Riyad: Dar al-'Asimah.

Sarwat. Ahmad. Seri Fikih Kehidupan (Mukaddimah). Jakarta Selatan: Rumah Fikih Publishing.

Sulaiman. Abu Daud al-Sijistani. (t.th). Al-Sunan. Beirut: Dar al-Fikri.

Suryabrata. Sumadi. (1987). Metode Penelitian. Jakarta: Rajawali.

Tanjung. Armaidi. (2007). Free Sex No Nikah Yes. Jakarta: Amzah.

Tim Redaksi Nuansa Aulia. (2017). Kompilasi Hukum Islam (KHI). Bandung: CV. Nuansa Aulia.

Tim Ulin Nuha Ma'had Aly al-Nur. (2018). Fiqh Munakahat. Solo: Kiswah Media.

Umar. Husein. (2013). Metode Penelitian untuk Skripsi dan Tesis. Jakarta: Rajawali.

Umar. Ibnu al-Mulaqqan. (2004). al-Badru al-Munir. Riyad: Dar al-Hijrah li al-Nasyr wa al-Tawzi'.

Usman, M. H., \& Yunta, A. H. D. (2020). Koreksi Hukum Islam Terhadap Hukum Jahiliah. BUSTANUL FUQAHA: Jurnal Bidang Hukum Islam, 1(1), 1-15.

Wizarah al-Awqaf wa al-Syu'un al-Islamiyyah. (2007). al-Mawsu'ah al-Fiqhiyyah alKuwaitiyyah. Kuwait:Dar al-Silal.

Yahya. Al-Nawawi. (1997). Al-Majmu'Syarh al-Muhazzab. Beirut: Dar al-Fikri.

Yusuf. Ibnu Abdu al-Barr. (1428 H). al-Tamhid Lima fi al-Muwatta' min al-Ma'ani wa al-Asanid fi Hadis Rasulilah. Lebanon: al-Maktabah al-Asriyyah. 